\title{
Szolidaritás a késő modernitásban
}

\author{
Sik Domonkos \\ https://doi.org/10.51624/SzocSzemle.2018.1.1 \\ Beérkezés: 2017.03. 23. \\ Átdolgozott változat beérkezése: 2017. १२. १२. \\ Elfogadás: 2018. 02. 21.
}

\begin{abstract}
Összefoglaló: A tanulmány célja, hogy kísérletet tegyen az integrációs és morálfenomenológiai szempontból egyaránt kulcsfontosságúnak tekintett szolidaritás késő modern sajátosságainak jellemzésére. Első lépésben a vallási-rendi paradigmát felváltó társadalombiztosítási logika kialakulásának, majd - a globális információs társadalom expanziója következtében - kérdésessé válásának bemutatására kerül sor. Második lépésben a szolidaritás késő modern lehetőségterének rekonstrukciójára teszek kísérletet. A Bourdieu, Habermas, Giddens és Lash integrációs modelljeinek megfelelő módon szerveződő társadalmi terekben adekvát (szenvedéshez segítési hálózat kapcsolódik), inadekvát (segítési hálózat nem szenvedéshez kapcsolódik) és hiányzó (szenvedéshez nem kapcsolódik segítési hálózat) szolidaritási formákat dolgozok ki. Harmadik lépésben, ezekre támaszkodva, a premodern, klasszikus és késő modern szolidaritás ideáltipikus paradigmáit mutatom be.
\end{abstract}

Kulcsszavak: szolidaritás, késő modernitás, kritikai elmélet

Annak ellenére, hogy a szolidaritás a klasszikus szociológia egyik kulcsfogalma, világos definiálása korántsem könnyű feladat. ${ }^{1}$ A fogalom elsődleges haszna heurisztikus értékéből fakad: arra az elemi kötelékre utal, amely tetszőleges társulás fennmaradásához nélkülözhetetlen. A társulás minden tagja rá van utalva a többiekre abban az értelemben, hogy potenciálisan rászorul materiális vagy szimbolikus segítségnyújtásukra; emellett minden taggal szemben megfogalmazódnak a többiekért hozott áldozatokra és erőfeszítésekre vonatkozó elvárások, potenciális segítővé téve őket. ${ }^{2}$ Ilyenformán a szolidaritás, a rászorultság és a segítségnyújtás normatív kereteit kijelölve a társakhoz tartozás elemi kötelékét hozza létre - ebben az értelemben a társulások integrációjának kulcsa. A szolidaritásra vonatkozó kérdés egyidős a szociológia kialakulásával: abból a modernizációs tapasztalatból táplálkozik, hogy az együtt cselekvés személyes-közösségi kapcsolatokon és hagyományközösségen alapuló motivációi és keretei egyre kevésbé képesek a társadalom integrációjára (Durkheim 2001; Tönnies 2004). Ebben a helyzet-

1 A szolidaritás fogalmát igyekszem kellően tág értelemben használni ahhoz, hogy szubsztantív társadalomtörténeti és formális társadalomelméleti koncepciókhoz egyaránt hozzá lehessen kapcsolni. Ilyenformán az alábbi írás egyszerre tekinthető történeti és analitikus definiálási kísérletnek.

2 Az alábbiakban az empirikus kutatások által használt, részletesebben kidolgozott szolidaritásdefiníció helyett (vö. pl. Ferge 2000; Janky 2011; Takács 2015, 2016; Utasi 2002, 2013) azért támaszkodom erre az általános értelmezésre, mert a segítségnyújtás és felelősségvállalás lehetőségterének rekonstrukciójához a releváns jelenségek lehető legtágabb körének inklúziójára van szükség. 
ben válik kérdésessé, hogy milyen alternatív mechanizmusok lépnek helyükre, és mindez milyen - emancipatorikus és patologikus - következményekkel jár.

Az integráció mellett a szolidaritás a modernitás morálfenomenológiájának is a kulcsfogalma. A közösségi típusú kapcsolatokból kilépve számos megválaszolandó kérdéssel találja magát szemben a cselekvő: korántsem magától értetődő ugyanis, hogy az általa személyesen nem ismert, életvilágában nem osztozó, vagyis „idegenként” adott másikkal szemben milyen kötelességei (milyen helyzetekben és kinek kell segítséget nyújtani?) és elvárásai (kitől várható el, hogy szükség esetén támogatja?) lehetnek. Ez pedig nem csupán a másikhoz való viszonyt terheli meg többletkontingenciával, de potenciálisan magát a társadalmasulást teszi kérdésessé. Attól kezdődően, hogy a másikkal szembeni morális elvárások és kötelességek többé nem naturalizált, magától értetődő formában adottak, a reciprocitással szemben elemi kétely támad: egyaránt lehetséges, hogy a másik nem teljesíti kötelességeit és magára hagyja az egyént a bajban (kiilleszkedés-problematika), valamint az is, hogy az egyén kibújik felelőssége alól és nem nyújt segítséget (potyautas-problematika). E lehetőségek valószínűségét mérlegelve végső soron az is kérdésessé válhat, hogy az egyénnek érdemes-e társulnia a többiekkel.

Azt, hogy e felvetéseket korántsem csupán egy absztrakt elméleti kíváncsiság motiválta, mindennél jobban mutatja az az aggodalom, amely kíséri őket. Alig van ugyanis olyan klasszikus elméletalkotó, aki valamilyen formában ne vetné fel a szolidaritás végzetes torzulásának vagy éppen felszámolódásának lehetőségét. Vagyis az elemi szolidaritási szálak drasztikus meggyengülése, a morális kötelmek és elvárások elbizonytalanodása végső soron a társadalmi dezintegráció lehetőségét vetíti előre: egy olyan állapotot, ahol az egyének immár nem feltétlenül, vagy egyáltalán nem érdekeltek a társulásban. Noha a különböző elméletek az aggodalom mellett többnyire arra is kísérletet tesznek, hogy alternatív integrációs mechanizmusok felvillantásával különböző kiutakra is rámutassanak, a szolidaritáshiánnyal összefüggő dezintegráció fenyegető képe végigvonul a szociológia történetén. Így újabb és újabb formában merül fel a kérdés: milyen mechanizmusok pótolhatják a modernitás változó keretei között a közösségi szolidaritást?

Az alábbi tanulmány kiindulópontját a fenti megfontolások alkotják. Első lépésben arra teszek kísérletet, hogy rekonstruáljam a szolidaritás késő modernitásbeli állapotát és annak előtörténetét Robert Castelnek a szociális kérdés alakváltozását áttekintő társadalomtörténeti elemzése és Manuel Castells hálózati társadalomra vonatkozó elképzelései alapján. Bár e két elemzés mind elméleti hagyományait, mind vizsgálódási körét tekintve különbözik egymástól, abból a szempontból összefüggenek egymással, hogy a tág értelemben vett szolidaritás történetének és kihívásainak átfogó leírására vállalkoznak. Ezért kapcsolom legfontosabb belátásaikat egymáshoz az első fejezetben: úgy gondolom, hogy következtetéseik lehetőséget kínálnak a késő modern társadalmak szolidaritási kihívásainak ideáltipikus jellemzésére. Mindezek tanulsága szerint napjainkban a szolidaritás története fordulóponthoz érkezett: a 
bérmunka társadalmában kialakult, a második világháború utáni évtizedekben rendszerszinten stabilizált szolidaritási paradigma kérdésessé vált. Ennek következtében egyszerre azonosíthatók dezintegrációs tendenciák (kényszerből és önként kiilleszkedettek számának növekedése), új integrációs szinten megvalósított szolidaritási technikák (intencionális és rendszerszint helyett kibernetikai szinten), valamint a szolidaritás morális alapjainak regresszív (új nacionalizmusok, az együttmúködés minimalista felfogását tükröző neoliberalizmus) vagy progresszív újraértelmezésére való törekvések (gendermozgalmak, új morális alapot kereső globalizációkritika).

Minthogy empirikusan ezek különböző mintázatai valósulnak meg, így öszszességében nem csupán a klasszikus modernitás szolidaritási paradigmájának meggyengüléséről beszélhetünk, hanem az erre adott divergáló reakciókból fakadó fragmentálódásról is. Ebben a helyzetben különösen égető kérdés, hogy a szolidaritás klasszikus modernitásbeli formáinak romjain „hogyan lehetséges szolidaritás”? A tanulmány második szakaszában ezt a kritikai elmélet keretei közt megválaszolható kérdést járom körbe. A kritikai elméletek a valóságot annak lehetséges formái felől próbálják megérteni, így a fennálló viszonyok mellett kulcskérdés számukra az utópikus horizontok feltárása is (Horkheimer 1976). Ebben a keretben a szolidaritás megértésére annak tág lehetőségtere felől nyílik mód. A válasz kidolgozásakor éppen ezért egy olyan elméleti modellhez fordulok, amelynek segítségével a különböző társadalmi helyzetekből fakadó, eltérő szolidaritási mintázatok egységes keretben ragadhatók meg. E célból a kritikai elméletek - korábban részletesebben bemutatott - hálózati modelljére támaszkodom (Sik 2012, 2015a, 2017, 2018). A hálózati megközelítés segítségével a kötések olyan összetett tere tárul fel, amelyben értelmezhetővé válnak a hiányzó, az inadekvát és az adekvát segítés különböző integrációs szintű formái. Ezek alapján leírható a premodernitás, a klasszikus és késő modernitás szolidaritási paradigmája, továbbá megválaszolható a kérdés, hogy miként helyezhetők új alapokra a bizalom és felelősségvállalás erodálódott formái.

\section{A kérdéses szolidaritás: a jóléti állam kialakulása és válsága}

Minden társadalom szembesül azzal a kérdéssel, hogy mit kezdjen az önellátásra képtelen tagjaival. Abban az esetben, ha ez életkori sajátosságból (gyerekek, idősek), valamilyen „objektíven” belátható ideiglenes (pl. betegség) vagy tartós munkaképtelenségből (csökkent munkaképesség) fakad, a válasz kevésbé ambivalens: a közösség tagjai a rendelkezésükre álló források függvényében, normatív keretek által szabályozott módon biztosítják legalább a minimális létfeltételeket. Természetesen maga az „objektív munkaképtelenség” adott társadalomtörténeti konstellációhoz kötött értelmezés függvénye, így a társadalom támogatása sohasem magától értetődő, hanem definíciós és határmegvonási küzdelmek eredményeként áll elő. Teljesen más megítélés alá esik ugyanakkor az a helyzet, amikor ilyen objektívnak látszó okok nem azonosíthatók, azonban az egyén mégsem képes munkavégzésre. Ennek hátterében egyaránt állhat a szakértelmének megfelelő munka hiánya 
vagy a munkavégzéshez való jog - akár „idegenségre”, akár „illetéktelenségre” hivatkozó megtagadása. Belátható, hogy ez paradox helyzetet eredményez: egyszerre lehetetlenül el az egyén önellátása és kerül kívül a minimális létfeltételeket biztosítani hivatott közösségi gondoskodási hálón. Ráadásul, minthogy nincs stabil jövedelme, teljességgel kiszámíthatatlan elemmé válik, aminek következtében potenciális veszélyforrásként jelenik meg a társadalom számára (Castel 1998: 27--28).

Ez az elemi gyanú határozza meg a középkortól kezdődően a „munkavégzésre fizikailag képes munkanélküli” szerepének megítélését, kijelölve a „kiilleszkedetthez” való viszony későbbi kereteit. E szerep első ideáltipikus megtestesítői azok a csavargók voltak, akik lakóhelyüktől távol kényszerülve munkát keresni, kiszakadtak a szolidaritás feudális kötéseiből. E kötések egyszerre voltak hivatottak szavatolni a megélhetés tartós kereteit és az esetleges munkaképtelenség idejére vonatkozó gondoskodást. A csavargó életforma ezért a kiszolgáltatottság extrém formájával járt. Ennek ellenére, ahogy fokozódó igény mutatkozott a szabadon mozgó, áruként létező munkaerőre, egyre kevésbé számított ritkaságnak már a preindusztriális korszakban is. A csavargó figurájának és a hozzá kapcsolódó szolidaritási formáknak a tétjét ilyenformán az adja, hogy a „bérmunka prototípusaként” kijelölik azokat a diszkurzív sajátosságokat, melyek a szolidaritás történetét keretezik a modernitásban (Castel 1998: 29).

A bérmunkásként felfogadott csavargóhoz környezete egy a szociális dimenziójától megfosztott, kizárólag gazdasági jellegú viszonyulással kapcsolódik. Munkaerejére csak epizodikusan van szükség, az ellentételezés kizárólag valamilyen konkrét elvégzett feladathoz kapcsolódik, miközben a munkalehetőség esetleges. Ebben az értelemben a preindusztriális keretek között bérmunkássá váló csavargónak nincs semmilyen lehetősége arra, hogy a létfenntartását hosszú távon szavatoló biztosítékokra tegyen szert. Ez a periferikus léthelyzet a szolidaritás újkori történetének kiindulópontja: a kérdés az, hogy miként alakult át ez az epizodikus, a szociális dimenziótól megfosztott, szélsőséges kiszolgáltatottsággal járó bérmunkaviszony.

A feudális társadalmak szolidaritási paradigmájának alapja a keresztény moralitásba ágyazott segélyezés volt. Az eredetileg univerzális könyörületességi imperatívusz („segíts felebarátodon!”) a feudális reciprocitás gyakorlatában kettős határmegvonással egészült ki: egyfelől a szenvedés testi szinten való kifejeződéséhez, másfelől a lokalitás elvéhez kötődött (Castel 1998: 40-47). Ezek a vonások öröklődtek át a csavargók számára nyújtott segítségnyújtás gyakorlatára is, melyet az „üdvgazdaságtan" racionalitása mellett praktikus szempontok is szerveztek. A feudális rendből kiilleszkedett nincstelen csavargó lokálisan, testi szenvedése mértékében segélyhez jutott, ugyanakkor ezt az elkülönítés és átnevelés logikájával ötvözték (dologházak, ispotályok, imaházak), továbbá mozgását büntetőjogi eszközökkel korlátozták (nem helybéliek koldulásának tiltása). Ezek az intézkedések összességében a bérmunkáscsavargók felügyeletét voltak hivatottak szavatolni: megpróbálták őket abban a két értelemben helyhez kötni, hogy vándorlásukat ellehetetlenítik, a településen belüli tevékenységüket pedig kontrollálják (Castel 1998: 50-53). 
A rendi társadalom keretei között a legszegényebbek szolidaritási csapdába kerültek: miközben a mobilitás gazdasági kényszere erősödött (különösen olyan események következtében, mint a nagy pestisjárvány), a helyben maradás normatívhatalmi logikája ezt egyre inkább ellehetetlenítette. E feszültség az ipari forradalom kezdetéig meghatározó maradt, meghatározva a munkaerő felszabadulásának társadalmi drámáját. A feudális rend szolidaritási hálójából hosszú évszázadokon keresztül kiesők arra kárhoztattak, hogy egyszerre várták el tőlük a munkavégzést, miközben megtagadták tőlük a munkakeresés jogát. Ráadásul, ahogy a számuk nőtt, úgy lett egyre durvább a régi rend nevében fellépő hatalom szankciója is: a bérmunkától elválaszthatatlan kísérőjelenségeknek tekinthető csavargás és koldulás nemritkán kényszermunkát, gyarmati száműzetést, gályarabságot vagy végső esetben halálbüntetést vont maga után (Castel 1998: 79-86).

E feszültségekkel terhelt, megmerevedett konstellációból a falusi és városi feudális struktúrák lebontása jelentett kiutat. Attól azonban, hogy a bérmunkás megszűnt kirekesztett lenni, még korántsem vált automatikusan a társadalom integrált, elismert tagjává. Bár a bérmunka szabad felek közti szerződéses viszonnyá alakul át, nem garantálta sem a kiszámítható munkalehetőséget, sem pedig a munkaképesség elvesztésének időszakára kiterjedő gondoskodást. A szolidaritás kora modern formái dinamikus képet mutatnak: különböző privát (filantróp civilek, patronáló munkaadók) és munkavállalói (önsegélyezés) aktorok tesznek kísérletet arra, hogy ellensúlyozzák a bérmunkás kiszolgáltatottságát (Castel 1998: 191-193). Az esetleges filantrópia, a korlátozott önsegélyezés és az autonómiát felszámoló munkaadói patronálás - különböző okokból bár, de - végül egyaránt zsákutcának bizonyultak, helyettük választ végül a segélyezési logika helyére lépő biztosítási rendszer kínált.

A kötelező befizetésen alapuló, általános társadalombiztosítás a munkához való jog korábbi követelését beillesztette a bérmunkával kapcsolatos kockázatok általánosabb keretei közé: a munkanélküliség egyike lett a munkavégzést ellehetetlenítő veszélyeknek a baleset, betegség vagy időskor mellett. Ezen a ponton a bérmunka történetének egy fontos fejezete lezárult: a bérből élők kiszolgáltatott, bizonytalan helyzetét felváltotta a biztosítási rendszer révén tartósan integrált pozíció. E jogi formát öltő szolidaritás ugyanakkor korántsem tekinthető a történet végpontjának. Bár a gazdasági növekedés azt az illúziót keltette, hogy a bérmunka története egy rendszerszinten integrált, általános létbiztonságot szavatoló modellben teljesedett ki, melyet ugyan folyamatosan tökéletesíteni kell, ám lényegi módosításra nem szorul, ezt végül az 1970-es évek olajválsága, majd az azóta egyre általánosabbá váló munkanélküliség lerombolta. A munkanélküliség a biztosításon alapuló szolidaritás szempontjából végzetes fenyegetés. A munkájukat tartósan vagy rendszeresen elvesztők ugyanis kívül kerülnek a szolidaritási hálón, ezáltal pedig hasonlóképpen kiszolgáltatottá válnak a feudális társadalmak csavargóihoz: a közösségi és jogi szolidaritáson kívül rekedve immár senki sem vállal felelősséget értük. Ráadásul - szemben az egyéb munkaerőpiaci kockázatokkal - a munkanélküliség olyan veszély, mellyel kapcso- 
latban a társadalombiztosítási rendszer csak korlátozottan szolgáltathat védelmet. Amennyiben ugyanis a munkaerőpiaci ingadozások következtében a munkaerő-kereslet tartósan alulmúlja a kínálatot, a biztosítás egésze finanszírozhatatlanná válik, a társadalombiztosítási rendszer összeomlik (Castel 1998: 249-261).

A jóléti állam belső anomáliái felvetik ugyan a kérdést, hogy miként folytatható a közösségiből rendszerszintűvé vált szolidaritás története, megválaszolásához azonban ez a modell már nem kínál eszközöket. ${ }^{3}$ Ehhez a késő modernitás azon társadalmi és kulturális változásainak szisztematikus áttekintésére van szükség, melyek kijelölik a szociális állam válságba került szolidaritási paradigmájára adható reakciók horizontját. Természetesen e célból számos elmélet felhasználható, azonban ezek közül kiemelkednek Manuel Castells hálózati társadalomra vonatkozó munkái. ${ }^{4}$ Ezekben egyszerre vet számot a nemzetállami keretek között szerveződő bérmunkán alapuló szolidaritási paradigmát alapjaiban megkérdőjelező két változással: a nemzetállami kereteket felszámoló globalizációval és a bérmunka feltételeit átalakító információs termelési móddal. ${ }^{5} \mathrm{Az}$ ezek nyomán azonosítható újfajta társadalmasulási formák a szolidaritás lehetőségterét is elemi szinten alakítják át. Castells álláspontja szerint a 20. század vége korszakhatárnak tekinthető: ekkorra körvonalazódott a társadalmasulás olyan új formája, aminek egyaránt részét képezi a hálózati szerveződési forma, az információs termelési módon alapuló globális gazdaság, és - mindezek értelmezési horizontjaként - a valódi virtualitás kultúrája. E hatások összességeként alapjaiban rajzolódott át a társadalmi interakciók szerkezete és az intézmények müködési rendje (Castells 2010c: 372).

Hálózatok felépülhetnek tetszőleges egységekből: a világ pénzpiacát alkotó tőzsdék, döntéshozó politikusok vagy éppen a drogtermelés és -kereskedelem különböző aktorai egyaránt létrehozhatnak hálózati struktúrákat. Ezek közös jellemzője, hogy térbeli és időbeli keretektől függetlenül szerveződnek: a hálózat tagjai közötti távolságot elsősorban a topológiai jellemzők határozzák meg (hány csomópont érintésével jutnak el egymáshoz), nem pedig a fizikai paraméterek (tér- és időbeli közelség). A hálózat ennek megfelelően tetszőlegesen bővíthető, flexibilis struktúra, melyben az egyedüli korlátot a tagok közti kommunikáció feltételeinek biztosítása jelenti. Ha akár technikai okokból, akár közös kódok hiányában az új tagok inkompatibilisnek bizonyulnak, a hálózat növekedése megáll. A hálózatok további fontos sajátossága diszkrét határmegvonási jellegük: adott cselekvőt az jellemez, hogy milyen hálózatokhoz kapcsolódik potenciálisan és ténylegesen. Minthogy kizárólag a hálózatot alkotó

3 Utolsó munkáiban Castel továbbra is megmarad eredeti elemzési keretei között, figyelmét a bérmunka bizonytalanná válásának dimenzióira fókuszálva (Castel 2009, 2016).

4 Így például Castellshez hasonló mélységű elemzésként megemlíthetők Boltanski-Chiapello „kapitalizmus új szelleméről” (1999), Bauman „likvid modernitásról” (2000) vagy éppen a legújabbak közül Rosa „gyorsulási társadalomról” (2010) írt könyvei. Noha külön-külön a fókuszba állított dimenziók szerint alighanem sok szempontból messzebb jutnak, mint Castells, az alábbiakban mégis az ő elméletét választottam, mert segítségével átfogó kép rajzolható a szolidaritás kihívásairól.

5 Castells elméletét sokan - köztük olyan nagynevű teoretikusok, mint Giddens (1996) - egyöntetű lelkesedéssel fogadták, Marx és Weber meghatározó munkáihoz hasonlítva jelentőségét. Kevésbé elfogult értékelések ugyanakkor rámutatnak, hogy bár a feldolgozott témák mennyisége, és az új társadalmi jelenségek azonosítása kétségtelenül impresszív, azonban - szemben Marxszal vagy Weberrel - mind az általa használt fogalmi apparátus kidolgozottsága, mind az oksági elemzések megalapozottsága elmarad a klasszikusokétól (Van Dijk 1999: 128; Friedman 2000). 
csomópontokhoz kapcsolódva nyílik lehetőség a hálózat működésének befolyásolására, így a kizárás válik az új típusú egyenlőtlenségek és a hatalmi viszonyok legfontosabb szervezőelvévé (Castells 2010a: 500-501).

Fenti tulajdonságai okán a hálózati integrációs logika nem egyszerúen ideális alapot szolgáltat a piaci ingadozásokhoz igazodó kapitalista termelés számára, hanem egyúttal lehetőséget teremt annak megújítására és expanziójára is, aminek legnyilvánvalóbb kifejeződése a globális pénzpiacok kialakulása. Ahogy létrejöttek a technikai feltételei egy olyan kommunikációs apparátusnak, amely valós időben képes közvetíteni a globális pénzügyi adatokat, a pénzpiacok múködése alapjaiban változott meg. A befektetési döntéseket egyre inkább olyan matematikai algoritmusok határozták meg, melyek a világ különböző tőzsdéin lefolyt tranzakciókból nyert információkat veszik alapul. Ennek következtében az információ áramlása lesz az, ami döntő mértékben kihat a tőkemozgásokra. Minthogy ezek a reálgazdasági folyamatoktól nemritkán függetlenek, a pénzpiacok egy „párhuzamos valóságot” hoznak létre. E globális pénzpiaci valóság, abból fakadóan, hogy önreferenciális (saját trendjei megfigyeléséből nyer információt), hajlamos hatalmas piaci kilengésekre, melyek hatása ugyanakkor a reálgazdaságot sem hagyja érintetlenül - különösen úgy, hogy a globális pénzügyi szektor súlya folyamatosan nő: a kereskedelem elektronikussá válásával párhuzamosan emelkedik a globális pénzpiacokon lefolytatott tranzakciók mennyisége és mérete (Castells 2010a: 155).

Ez az új gazdasági világrend értelemszerủen alapvető változásokat indított be a munkaadók és munkavállalók viszonyaiban. Ebben az értelemben beszélhetünk a „hálózati vállalatok” új világáról, melyek nem egyszerúen következményei az információs technológia elterjedésének, hanem maguk is médiumai e folyamatoknak. Mindennapi gyakorlatukba átültetve, ezek a vállalatok transzformálják végső soron materiális valóssággá a globális hálózati társadalom szüntelen adatfeldolgozáson alapuló kultúráját, egyúttal áruvá változtatva az információt (Castells 2010a: 187-188). A hálózati vállalatot az „informacionalizmus szelleme” mozgatja: a valóság egy olyan konstrukciója, amely a globálisan hozzáférhető adatok szüntelen összegyújtésén és feldolgozásán alapulva maga is folyamatosan változik (Castells 2010a: 210-215).

E globális struktúra transzformációs és mobilitási tendenciáit erős polarizáció jellemzi. Egyrészt globális szinten elkülönülnek azok a centrumországok, melyekben elsősorban az értékteremtés, hálózatépítés és döntéshozatal szempontjából privilegizált csoportok aránya nő, és azok a periferiális országok, melyekben az alávetett pozícióban lévők aránya. Másrészt lokális szinten is megfigyelhető a társadalmi egyenlőtlenségek fokozódása: noha a helyi társadalompolitikától függően e tekintetben nagy különbségek figyelhetők meg, a leszakadók arányának növekedése az olyan centrumországokra is jellemző, mint az Egyesült Államok vagy Anglia (Castells 2010a: 296-302). A hálózatokból tartósan kirekesztettek az információs kapitalizmus „fekete lyukait” hozzák létre. Ezek olyan helyek (városrész, város, régió vagy akár ország is) és társadalmi csoportok (pl. hajléktalanok, írástudatlanok, szenvedélybete- 
gek), melyekre a globális információs társadalomnak nincs szüksége, és amelyek ezért láthatatlanná válnak.

További általános, mindenkit érintő tendencia a jogi garanciákkal övezett, teljes állású, kiszámítható karriert felkínáló, határozatlan idejű szerződésen alapuló bérmunkaviszony eltűnése. Minthogy a globális hálózati vállalatok számára a piaci igényekhez való igazodás mindennél fontosabb, így flexibilis termelésre igyekeznek berendezkedni. Ennek költségeit ugyanakkor elsősorban a munkavállalókra hárítják: akár a gyakori munkahelyváltás kényszerére, akár a részmunkaidős, határozott idejű szerződésekre utalunk, a kiszámítható, stabil munka ellehetetlenülésének jeleit látjuk. Mindezen hatások a munka életvilágbeli beágyazódását akadályozzák, más szóval felszámolják azt a lehetőséget, hogy a bérmunkára alapozva olyan többé-kevésbé stabil életet lehessen berendezni, ami magában foglalja a létfenntartásra és családalapításra vonatkozó társadalmi biztosítékokat. Ebben az értelemben válik a globális tőke és a lokális munka közti konfliktus legélesebb következményévé a bérmunkás lét elemi kiszámíthatatlansága, kiszolgáltatottsága és sebezhetősége (Castells 2010a: 280-289). Ezt kiegészíti továbbá az is, hogy a globális idő felülírja mind a munka és pihenés napi ritmusát, mind pedig a napszakok, az életszakaszok, valamint a hétköznapok és ünnepnapok tradícióba ágyazódó, kollektív ritmusát. Azáltal, hogy a különböző hálózatokba való beágyazódás szerint eltérő időrezsimekhez rendeli hozzá az egyéneket, az egyéni hétköznapok szétzilálásához és a lokális közösségek fragmentálódásához vezet (Castells 2010a: 468-481).

$\mathrm{Az}$ információs társadalom kialakulása és az általa beindított változások reakcióra késztetik az egyéni és kollektív cselekvőket egyaránt. Ebben a helyzetben egy megfoghatatlan, megszólíthatatlan, globális hálózati logika által meghatározott kényszerstruktúra jelenléte alaptapasztalattá válik, aminek következtében a legitim identitások tere is beszűkül. Elsősorban a globálistól fenyegetve érzett lokális védelme alapján szerveződő ellenállás vagy különféle, a megújulás ígéretét magában hordozó identitásformák válnak dominánssá (Castells 2010b: 6-12). E kihívásokra a nemzetállamok a maguk keretei között próbálnak megoldásokat találni. A gazdaság globalizációjával sokkal kevésbé képesek kontrollálni a saját határaikon belül zajló gazdasági-társadalmi folyamatokat, így kiszolgáltatottá válnak olyan válságoknak is, melyek adott esetben tőlük teljesen független államokon belül alakulnak ki. Ez a relatív pozícióvesztés ugyanakkor korántsem jelenti azt, hogy egyúttal jelentéktelenné is válnának: a nemzet továbbra is kitüntetett identifikációs pont, a nemzetállamok pedig továbbra is központi fontosságú aktorai a hálózati társadalomnak. Így sokkal inkább azt lehet mondani, hogy a nemzetállamok egy feszültségekkel a korábbinál sokkal jobban megterhelt konstellációban múködnek, ami egyaránt magában hordozza - új szervezeti és legitimációs formákat kitermelő progresszív és - a hatalommal való visszaélés és bezárkózás logikáján alapuló - regreszszív átalakulásuk esélyét (Castells 2010b: 303-312).

A fentieken túl a nemzetállamok mozgásterének lecsökkenését - az állampolgárok számára különösen fájdalmas módon - a jóléti állam intézményeinek leépülése 
teszi érzékelhetővé. Mivel a modern állam legitimációs bázisának alapját a jóléti társadalombiztosítási rendszerek alkották, ezért azok finanszírozási nehézségei az állam egészét veszélybe sodorják. Miközben a főként nemzeti piacra termelő vállalkozások esetében a járulékokon keresztül érvényesíteni lehetett a társadalombiztosítás finanszírozását, a nemzetállamok keretein túlnyúló hálózati vállalkozások esetében ez korántsem magától értetődő. A piaci szabályozások csökkenése és a termelésbe bekapcsolható munkaerő-kínálat globálissá válása következtében a magas munkavállalói járulékokkal jellemezhető, fejlett jóléti államok komparatív hátrányba kerülnek. Ezt csökkentendő a jóléti rendszerek a relatíve kevésbé fejletthez kezdenek konvergálni. Más szóval, pusztán a globalizáció hatására, minden termelési szinten az lesz megfigyelhető, hogy a nemzetállamok az adott szintet jellemző minimális jóléti viszonyokat fogják reprodukálni, ami összességében a jóléti állam leépülésének negatív spirálját eredményezi. Ezt a hatást csakis egy globális szintű társadalombiztosítási megállapodás tudná ellensúlyozni, azonban ennek realitása csekély.

Emellett kivételes esetként olyan nemzetállamokat is találunk (pl. Finnország), amelyek a jóléti állam növelését az innovációs potenciál növelésének eszközeként használják. Ez azonban a kevésbé jellemző eset: ehelyett a legelterjedtebb nemzetállami stratégiák vagy defetista, vagy regresszív jellegúek. Azt, hogy a nemzetállamok válságából milyen utak vezetnek ki, elsősorban a nyilvánosság és a demokratikus intézmények stabilitása jelöli ki. A nyilvánosság új kereteit az információáramlás felgyorsulása mellett a szórakoztatás szempontjainak dominánssá válása fejezi ki: míg az előbbi tendencia hatására az egyszerű, képi kommunikáció terjed el, az utóbbi következtében a korábbi instrumentális vagy normatív szempontok helyét esztétikaiak veszik át (Castells 2010b: 375-381). A nyilvánosság ily módon beszükült terében a közös reflexiónak és az érvelő vitáknak a lehetősége egyaránt csekély lesz. Ennek pedig az információs hálózati társadalom által generált megannyi gazdasági, társadalmi és politikai kihívás idején különösen veszélyes következményei lehetnek: a progreszszív identitásmintázatok és nemzetállami válaszkísérletek helyét a problémákkal való szembenézés helyett a tagadásukból kiinduló, regresszív stratégiák vehetik át, melyek következtében a nehézségek könnyen válságba fordulnak át.

Ahogy a nemzetállamok inadekvát válaszokat adnak, miközben a mediatizált politikai teret kitöltő botrányok miatt a fennálló intézmények és aktorok elhiteltelenednek, úgy roppannak meg a hálózati társadalom keretei között maguk a reprezentatív demokrácia intézményei is. Ennek következtében kérdésessé válnak mindazok a többé-kevésbé konszenzuális intézményi alapok, melyek a második világháború utáni időszak relatív békéjét szavatolták. Ahogy a rendszerellenes populista mozgalmak előtt megnyílik az út, úgy nő meg a kiszámíthatatlanság globális és lokális szinten egyaránt. E turbulens történelmi helyzetben a demokrácia értékei persze korántsem tűnnek el nyomtalanul, ugyanakkor a globalizáció kihívásai szempontjából adekvát intézmények hiányában a tényleges cselekvésekbe való becsatornázásuk tere fragmentálódik. Ennek megfelelően a jelen egyfajta versenyfutásként érthető meg, 
melynek tétje az, hogy sikerül-e azt megelőzően feltalálni egy „információs demokrácia" új intézményeit, hogy a regresszív politikai erők diadalmaskodnának, és beláthatatlan következményű konfliktusokba borítva a világot, felszámolnák a hálózati társadalom alapjait (Castells 2010b: 402-418).

Míg Castel elméletére úgy tekinthetünk, mint a szolidaritás jóléti paradigmájának kialakulását, fénykorát és válságát leíró történeti áttekintésére, Castells azokat a társadalmi-gazdasági feltételeket írja le, melyek a defenzívába szorult jóléti paradigma mozgásterét keretezik. Ebben az értelemben a kettő kiegészíti egymást: Castells alapján megvilágítható, hogy a bérmunka rendszerén alapuló szolidaritás a belső nehézségek mellett (a bérmunkán alapuló szociális rendszer finanszírozása demográfiai okokból, valamint a gazdasági dekonjunktúra okán kétségessé válik) milyen - magán a társadalombiztosítási rendszeren túlmutató - további kihívásokkal néz szembe. A globális információs hálózatok elterjedése nyomán gyökeresen átalakul mind a bérmunka világa, mind pedig a nemzetállamok mozgástere, vagyis a szolidaritás szociális intézményi paradigmájának alapjául szolgáló mindkét komponens.

Castells leírásai alapján azt lehet mondani, hogy a bérmunkára alapozott biztosítási rendszer a munka világának globalizációból fakadó destabilizálódása folytán inadekváttá válik, a nemzetállam mint a jóléti állam múködtetője megszúnik szuverén lenni, a nyilvánosság mint a jóléti döntések meghozatalának terepe pedig egyszerre veszti el racionalitáspotenciálját és válik ellenállási identitások terepévé. Ebben a konstellációban úgy túnik, hogy a Castel által bemutatott szolidaritási paradigma nem egyszerűen defenzívába szorul, hanem eredeti formájában menthetetlen. Ennek megfelelően a jelenleg is zajló átalakulásokra úgy tekinthetünk, mint a szolidaritás történetének fordulópontjára, egy új paradigma formálódásának időszakára. Annak ellenére, hogy a szolidaritás szerkezetváltozásának iránya jelen pillanatban nyitott kérdés, az átalakulások lehetőségterének rekonstrukciójára kísérletet tehetünk.

\section{A szolidaritás lehetősége a késő modernitásban}

Ezen a ponton kulcsfontosságú feladat, hogy azonosítsuk azokat a cselekvéshelyzeteket, melyek döntő jelentőségúek a szolidaritás új paradigmájának formálódása szempontjából. A társakra való elemi rászorultság és a másikért vállalt elemi felelősség normatív rendje végső soron azokban a cselekvéshelyzetekben alakul ki, melyekben a szenvedés tapasztalata megjelenik. A szenvedés, akár átéli az egyén, akár kívülről tekinti, feleletkényszert von magával: vagy együttérzéshez és azon alapuló segítéshez, vagy közönyhöz és azon alapuló magára hagyáshoz vezet (Lévinas 1988). Ahogy a szenvedés tapasztalata által érintett interakciós helyzetekben a szolidaritás absztrakt elvei lefordítódnak konkrét valóságértelmezésekre és gyakorlatokra, úgy kerül sor a fennálló paradigma hallgatólagos vagy explicit jóváhagyására, kritikájára, esetleg megújítására. Ennek megfelelően a szolidaritás átalakulásának megértéséhez a kulcsot a szenvedés felerősödésének és enyhülésének lehetőségét magukban rejtő cselek- 
véshelyzetek rejtik. Ahhoz, hogy ezek legtágabb körét megragadhassuk, a szenvedés határállapotainak és a kvázi-terápiás hatásoknak a társadalmi integráció különböző aspektusait egyaránt magába foglaló kritikai hálózatelmélete szolgál segítségül.

Ennek egyik kiindulópontja a késő modernitás kritikai társadalomelméleteinek hálózati szintézise, melyben Bourdieu (2002), Giddens (1991), Habermas (2011) és Lash (1999) társadalomelméleteit ${ }^{6}$ Latour (2005) és White (2008) hálózatelméletei segítségével kapcsoltam egymáshoz. Ha a kritikai elméletekre - inkommenzurábilis értelmezési keretek helyett - úgy tekintünk, mint eltérő integrációs szinteken (preintencionális, intencionális, posztintencionális), különböző koordinációs logikák (egyenlőtlenségi, reflexív, kommunikatív, technikai) által szervezetett cselekvési terek párhuzamos leírásaira, lehetőség nyílik egy átfogó modellben elhelyezni őket. Ehhez a hálózatelméletek oly módon kínálnak segítséget, hogy belőlük kiindulva az elméletileg azonosított cselekvéskoordinációs mechanizmusokat kapcsolódások és blokkolások empirikusan megragadható mintázataiként (diszciplína, stílus, kontrollrezsim, mediátor) értelmezzük újra. Ilyenformán az elméletek episztemiológiai összeegyeztethetetlensége meghaladható: a különböző integrációs logikák által meghatározott cselekvések eltérő morfológiai és dinamikai adottságokkal jellemezhető hálózatokként lesznek megragadhatók (Sik 2015b, 2017).

1. táblázat: Kortárs kritikai elméletek (Bourdieu, Giddens, Habermas, Lash) alapján azonosított hálózattípusok (Sik 2017: 110)

\begin{tabular}{l|l|l|l} 
& preintencionális & intencionális & posztintencionális \\
\hline $\begin{array}{l}\text { egyenlőtlenségi } \\
\text { hálózatok }\end{array}$ & $\begin{array}{l}\text { inkorporált stratégiák } \\
\text { versengési diszciplínája } \\
\text { (habitus) }\end{array}$ & $\begin{array}{l}\text { naturalizált hierarchiák } \\
\text { stílusa (illúzió) }\end{array}$ & $\begin{array}{l}\text { szimbolikus és materiális } \\
\text { tőke kontrollrezsimje } \\
\text { (mező) }\end{array}$ \\
\hline reflexív hálózatok & $\begin{array}{l}\text { repetitív diszciplína } \\
\text { (rutin) }\end{array}$ & $\begin{array}{l}\text { szakértői tudások alapján } \\
\text { történő kockázatbecslés } \\
\text { stílusa (kognitív } \\
\text { reflexivitás) }\end{array}$ & $\begin{array}{l}\text { szakértői tudáson alapuló } \\
\text { interaktív kontrollrezsim } \\
\text { (reflexív intézmény) }\end{array}$ \\
\hline $\begin{array}{l}\text { kommunikációs } \\
\text { hálózatok }\end{array}$ & $\begin{array}{l}\text { kollektív emlékezet } \\
\text { sematizáló történetei } \\
\text { (életvilág) }\end{array}$ & $\begin{array}{l}\text { kölcsönös megértésre } \\
\text { törekvő interakció stílusa } \\
\text { (kommunikatív cselekvés) }\end{array}$ & $\begin{array}{l}\text { médiumok által } \\
\text { szerveződő kontrollrezsim } \\
\text { (alrendszer) }\end{array}$ \\
\hline technikai hálózatok & $\begin{array}{l}\text { ingerek áramlásának } \\
\text { diszciplínája (információ) }\end{array}$ & $\begin{array}{l}\text { autonóm } \\
\text { értelemképződés stílusa } \\
\text { (esztétikai reflexivitás) }\end{array}$ & $\begin{array}{l}\text { materiális mediátorok } \\
\text { (technikai-tárgyi } \\
\text { környezet) }\end{array}$
\end{tabular}

A másik kiindulópont a szenvedés határállapotait és a kvázi-terápiás hatásokat valószínűsítő hálózati formák azonosítása a pszichológiai-pszichiátriai diskurzusokban „patologikusként” azonosított viselkedésmintázatok és „terápiásként” jellemzett cselekvéshelyzetek alapján. Ezekre úgy tekinthetünk, mint a szenvedés szélsőséges formáival kapcsolatba kerülő, annak csökkentésére vagy megszüntetésére törekvő

6 Az eredeti elemzésekben Honnethtel egészült ki ez a lista, terjedelmi okokból azonban ezúttal kihagyom az elismeréselméleti szempontokat. 
megismerésérdek által meghatározott leírásokra. Noha a pszichológiai-pszichiátriai megismerés többnyire természettudományos-biológiai keretben érti meg önmagát, és ennyiben nem mentes sem a „szcientista önfélreértéstől” (Habermas 2005), sem pedig az episztemiológiai paradoxonoktól (Foucault 2004), az általa létrehozott leírásokra mégis úgy tekinthetünk, mint a cselekvési képesség beszúkülésével járó szenvedéseknek és azok enyhítési módjainak a rendelkezésre álló legteljesebb, szisztematikus katalógusára. Az e leírások alapján hálózatelméletileg rekonstruálható szocializációs pályák ilyenformán magukban rejtik a lehetőségét egy közvetlenül a társadalmi okokra visszavezethető szenvedések tapasztalatából kiinduló normatív bázis kidolgozásának (Sik 2015b, 2016a, 2016b, 2018).

A rászorultság és segítés lehetőségterének társadalomelméleti felvázolásakor ez az átfogó megközelítés szolgál kiindulópontként. Egyfelől minden olyan hálózat, mely a szenvedés valamely határállapotát valószínűsíti, potenciális rászorultsági pozíciókat jelöl ki. Másfelől minden olyan hálózat, mely kvázi-terápiás kötéseket tartalmaz, a segítés lehetőségét hordozza magában. E pozíciók hálózati szinten történő azonosításával a szolidaritás kérdése eloldódik a konkrét cselekvőktől, és ehelyett hálózati konfigurációként lesz megragadható. Szolidaritási hálózatokról beszélhetünk abban az esetben, ha a szenvedés valamely határállapotát valószínűsítő torzuláshoz adekvát kvázi-terápiás kötés kapcsolódik. Az ilyen konfigurációk nem csupán általánosságban hagyják jóvá a szolidaritást, hanem egyúttal megerősítik a kvázi-terápiás kötés formájának megfelelő paradigmát is. Abban az esetben, ha torzult hálózatokhoz nem kapcsolódnak adekvát terápiás kötések, a szolidaritás hiányából fakadó vákuumról beszélhetünk. Az ilyen konfigurációk a magára hagyottság érzéséhez és a társadalmi kötelékekben való csalódáshoz vezetnek, összességében a szolidaritás paradigmájának erózióját eredményezve. Amennyiben a kvázi-terápiás hálózatok nem kapcsolódnak szenvedést okozó torzulásokhoz, úgy a szolidaritás inadekvátságáról beszélhetünk. Az ilyen konfigurációk a - szenvedéssel járó hálózatokról való lekapcsolódással öszszefüggő - érzéketlenség tapasztalatával járnak, összességében a szolidaritás értelmi kiürülését eredményezve.

A különböző integrációs formák ennek megfelelően a szolidaritás paradigmájának és kudarcainak mozgásterét egyaránt kijelölik. Az önmagukban álló torzult hálózatok a társadalmi felelősségvállalás vakfoltjait, a szenvedésről lekapcsolódott kvázi-terápiás kötések a segítés inadekvát kereteit, a torzult és kvázi-terápiás kötéseket egyaránt tartalmazó hálózatok pedig a szolidaritás stabilizálódásának lehetséges irányait jelzik. Adott szolidaritási paradigmát e három dimenzió együttesen jellemez: egyszerre jelölve ki a szenvedés társadalmi felelősségvállalás köréből kieső formáit, a segítő szándék diszfunkcióit és a rászorulók sikeres megsegítésének kereteit. Tetszőleges társadalomtörténeti konstelláció, valamint a szolidaritás hosszú távú átalakulásának íve egyaránt elemezhető ebből a szempontból. Az alábbiakban arra teszek kísérletet, hogy a szolidaritás hálózati komponenseit az egyes integrációs logikák vonatkozásában külön-külön áttekintsem: elsőként a szolidaritás hiányának, másodikként a 
szolidaritás kiürülésének, végül a szolidaritás adekvát formáinak egyes dimenzióit vázolva fel.

A szolidaritás kérdése a - bourdieu-i értelemben vett - habitusok révén szerveződő hálózatokban a különböző tőkékért folytatott küzdelmek szintjén merül fel. „Könyörtelen habitusról" beszélhetünk abban az esetben, ha a torzult habituális hálózatokhoz nem kapcsolódnak kvázi-terápiás kötések. Az ilyen hálózatokban a különböző tőkékért folyó társadalmi küzdelmek következményei kontrollálhatatlanná válnak: a harc kíméletlen lesz, és a cselekvők horizontjáról eltűnik a legyőzöttek iránti együttérzés lehetősége. „Öncélú habitus” figyelhető meg azokban a hálózatokban, ahol a kvázi-terápiás hálózatok nem kapcsolódnak torzultakhoz, és ennek következtében a materiális és szimbolikus tőkékért folyó küzdelmekben rejlő megújulási lehetőség kiaknázatlan marad. Az ilyen konstellációkban a játszmák öncélúvá válnak, ahelyett, hogy a bennük átélt tapasztalatok tágabb relevanciára szert téve hozzájárulnának a megakadt cselekvéshelyzetek átkeretezéséhez. „Sportszerű habitusról” beszélhetünk akkor, ha a kvázi-terápiás hálózatok a torzult hálózatokhoz kapcsolódva fair küzdelmet eredményeznek. A szenvedés ellensúlyozására ebben a konstellációban a méltányos versengés során átélt tapasztalatok hivatottak, melyek feltételeit a társak szavatolják.

Az illúziók révén szervezett hálózatokban a szolidaritás a szenvedések naturalizálásának és legitimálásának kapcsán értelmezhető. „Neoliberális illúzióról” beszélhetünk abban az esetben, ha a szenvedés megelőzése és kezelése az egyéni felelősség körébe sorolódik, és ebben az értelemben az iránta való közöny legitimmé válik. Ahogy a társadalmi patológiák magánüggyé válnak, úgy az együttérzés és felelősségvállalás helyett hatalmi viszonyok fejeződnek ki az egyenlőtlenségek és hierarchiák rendszerében, ellehetetlenítve a társadalmi konfliktusok pacifikálásának lehetőségét. „Idealizáló illúzió" jellemzi azokat a hálózatokat, melyek csupán olyan cselekvők számára kínálják fel a valóság elismerésre méltó olvasatát, akik szenvedés hiányában ebben egyébként sem kételkednek. A privilegizált, hatalmi pozícióban lévők zárványában nincs valódi tétje a torzulások enyhülésének, így az erre hivatott mechanizmusokról is nagyobb eséllyel alkotnak idealizált képet, elvétve azok javításának lehetőségét. ${ }^{7}$ „Teodícea illúzió” figyelhető meg azokban a hálózatokban, ahol a preintencionális, intencionális és posztintencionális kötésekből fakadó szenvedések olyan oksági keretbe ágyazódnak, melyben megmagyarázhatók és kezelhetők. A torzulások rendelkezésre álló szempontok szerinti megértésével és hozzáférhető eszközök révén történő enyhítésével a fennmaradó, kiküszöbölhetetlennek bizonyuló szenvedések egyúttal elfogadhatóvá is válnak.

A mezőlogika szerint szerveződő hálózatokban a szolidaritás a materiális és szimbolikus tőkék újraelosztásának szintjén ragadható meg. „Kontrollálatlan mezőről” be-

7 E típust fejezik ki az olyan - nemritkán pártpolitikai célokat szolgáló - társadalompolitikai intézkedések, melyek névleg valamely általános problémára kínálnak megoldást, valójában azonban csak partikuláris esetekben fejtenek ki ténylegesen is hatást (pl. családtámogatási rendszer: Darvas-Szikra 2017). 
szélhetünk abban az esetben, ha nincsenek olyan mechanizmusok, melyek az egyenlőtlenségeket lennének hivatottak kezelni. Az ilyen hálózatokban senki sem várhatja, hogy segítséget kap a társadalmi ranglétrán való előrejutáshoz, aminek következtében polarizálódnak a különbségek. „Elleplező mezőként” értelmezhetők azok a hálózatok, ahol a tőkeviszonyok egyenlőtlenségének következményei láthatatlanok. Ilyenkor a társadalmi különbségek korlátozott percepciója alakul ki, amely perspektívából a csökkentésükre irányuló törekvések is indokolatlannak tűnnek. ${ }^{8}$ „Redisztributív mezőről” beszélhetünk azokban a hálózatokban, ahol az alapértelmezésben beszűkült cselekvési terű egyének lehetőségeinek kitágítása a cél. Az ilyen hálózatokban egy olyan alternatív mezőlogika figyelhető meg, amelynek tétje az eredeti felhalmozáson alapuló, az egyenlőtlenségeket látens módon újratermelő hatások megakasztása vagyis a másikért vállalt felelősség.

A - giddensi értelemben vett - rutinok alapján konstruálódó hálózatokban a szolidaritás az ontológiai biztonság szavatolásaként írható le. „Feladott rutinokról” beszélhetünk azokban a helyzetekben, amikor a társas kényszerek hatására a cselekvő kénytelen lemondani a repetitív viselkedésmintázatok kialakításáról. Az ilyen hálózatokban a megbízható rutinok hiányával magára marad az egyén, aminek következtében a hétköznapi cselekvések kiszámíthatatlansága válik alaptapasztalattá. „Izolált rítusok" figyelhetők meg azokban a hálózatokban, ahol az ontológiai biztonság megújításának gyakorlatai nem fejtenek ki hatást a cselekvések tágabb terére. Az ilyen helyzetekben a rítusok zárványszerú, monologikus rendje jön létre, melyben a repetitív viselkedésmintázatok stabilizációs potenciálja csak korlátozottan tud érvényesülni. „Tradicionális rutinok” jellemzik azon hálózatokat, ahol a társadalmi patológiák kezelését repetitív cselekvésmintázatoktól várják. Az ilyen hálózatokban az ismétlődés olyan hozzáadott értékként jelenik meg, amely - biztonságérzetet teremtve - önmagában is hozzájárul a torzulások kezeléséhez.

A kognitív reflexivitás hálózataiban a szolidaritás a bizonytalanságok és kockázatok kezelésének lehetőségterében ragadható meg. „Hitelvesztett reflexivitásról” beszélhetünk abban az esetben, ha megrendül a racionális tudományos tudásba vetett hit. Amennyiben a cselekvők nem támaszkodhatnak a valóság ráció szempontjai alapján kidolgozott értelmezésére, kiszolgáltatottá válnak a hiedelmeknek, babonáknak és dogmáknak, melyek abban az értelemben becsapják őket, hogy nem kínálnak szisztematikus megismerési folyamatok sorozatában kipróbált eszközöket problémáik megoldására. „Valóságidegen szakértői reflexió” figyelhető meg azokban a hálózatokban, ahol pragmatikus receptek helyett absztrakt ismeretek válnak dominánssá. Az ilyen hálózatokban ahelyett, hogy a reflexió tényleges problémákra szolgáltatna megoldást, egyfajta üveggyöngyjátékként, pusztán elméleti kíváncsiságot elégít ki, végső soron magára hagyva szenvedéseivel a rászorulót. „Szcientista reflexióról” beszélhetünk akkor, ha a különféle társadalmi eredetű patológiák kezelését az illúziók-

8 E lehetőségre példaként hozhatók fel azok a társadalompolitikai programok, melyek müködését rejtett előitéletek határozzák meg (pl. közmunkaprogram: Ferge 2012). 
tól és elfogultságtól mentes racionális megismerésből származó ismeretek biztosítják. Az ilyen hálózatokban a felmerülő problémák kezelését a széles körben hozzáférhetővé tett szakértői ismeretek szavatolják.

A reflexív intézmények hálózataiban a szolidaritás a szakértők és a kliensek egymáshoz való viszonyának a szintjén értelmezhető. „Bemerevedett intézményekként” jellemezhetők azok a konstellációk, ahol az egyéni cselekvők szempontjainak a szervezet szabályozásába való becsatornázása ellehetetlenül. Az ilyen helyzetekben az egyének jelentéktelennek és a bürokratikus vagy hatalmi rendszerrel szemben védtelennek érzik magukat, és hosszú távon elveszítik a belé vetett bizalmat. ${ }^{9}$ „Tudományos intézményről” beszélhetünk akkor, ha a szenvedő cselekvők helyett a szakértői tudástermelés szempontjai válnak a hálózat szerveződésének alapjává. Ebben az esetben a kliensekhez való igazodási kényszer hiányában a tudományos ismeretek felhalmozásának logikája válik kizárólagossá, végső soron diszfunkcionálissá téve az intézmény múködését. „Reszponzív intézménynek” tekinthetők azok a hálózatok, melyekben a szenvedés tapasztalatait - az eldologiasító intézményi relációkat felváltó - személyre szabott interakciók képesek ellensúlyozni. Az ilyen konstellációkban az egyén arra vonatkozó tapasztalatokat él át, hogy a társadalom egésze számára fontos a szenvedése, továbbá azt minél hatékonyabban próbálja enyhíteni.

A - habermasi értelemben vett - életvilág logikája szerint szerveződő hálózatokban a szolidaritás a közös valóság magától értetődő sémáinak szintjén írható le. „Fragmentált életvilágról” beszélhetünk akkor, ha beszűkül a valóság közös értelmezésének a tere, és helyét egyéni interpretációs mechanizmusok veszik át. Az ilyen hálózatokban a cselekvők egyre kevésbé érzik úgy, hogy számíthatnak a többiekre a legkülönbözőbb jelentéstulajdonítási folyamatokban, és ilyenformán magukra maradnak e feladatokkal. „Kizáró életvilág” figyelhető meg azokban a hálózatokban, ahol a valóság természetesként adott, evidens értelme csak a létrehozásában érintett közösségen belül hasznosulhat. Minthogy ezek az értelmi tartalmak az adott tradíció-összefüggéstől elválaszthatatlan, zárt jelentések, nem képesek az attól független cselekvések alternatív horizontját megalapozni, így maguk is hozzájárulnak a befelé fordulás és közöny erősödéséhez. „Kisközösségi életvilág” jellemzi azon hálózatokat, ahol a szenvedés enyhítését a valóság naturalizált interpretációjához való visszatalálás teszi lehetővé. Az ilyen konstellációkban a jelentések esetlegességei és bizonytalanságai egy közös életforma megerősítése révén küszöbölődnek ki.

A kommunikatív cselekvés hálózataiban a szolidaritásra vonatkozó kérdés a kölcsönös megértés célja által szerveződő beszédaktusok vonatkozásában merül fel. „Kiüresedett kommunikatív cselekvés” jellemzi azokat a hálózatokat, melyekben a kölcsönös megértés lehetetlenségének tapasztalata meghatározó. Az ilyen hálózatokban a társadalom nem vállal felelősséget a személyközi viszonyok olyan demokratikus

9 Az ilyenfajta diszfunkciók különösen nagy eséllyel fordulnak elő az olyan ellátórendszerekben, melyek amiatt, hogy részfeladatokra koncentrálnak, végső soron kudarcot vallanak globális feladatukat illetően (pl. hazai utógondozó rendszer: Rácz 2012). 
rendjéért, melyben az érintetteknek egyenlő joguk van a közös döntések meghozatalában, és ebben az értelemben magára hagyja tagjait. ${ }^{10}$ „Illedelmes kommunikációról” beszélhetünk azokban az esetekben, amikor az interakció elveszti a tényleges érdekellentétek és véleménykülönbségek tisztázásából fakadó jelentőségét. Ha a vitapartnerek egyike számára sincs húsba vágó tétje a szóban forgó kérdésnek, akkor az esetleges kritika és konszenzus egyaránt súlytalan, és a morális megújulás lehetőségének helyét átveszi az illedelmesség blazírtsága. „Demokratikus kommunikáció” figyelhető meg azokban a hálózatokban, ahol a szenvedés enyhítése a valóság uralommentes vitában történő újraértelmezésének segítségével történik. Az ilyen értelemben a mikro- és makroszintű nyilvánosságok megerősítését megcélzó hálózatokban a közösség felelősségvállalása a közös döntési folyamatokban való részvétel formáját ölti.

A rendszerlogika szerint szerveződő hálózatokban a szolidaritás a szimbolikusan általánosított médiumok segítségével folytatott kommunikáció szintjén értelmezhető. „Le nem horgonyzott alrendszerekről” beszélhetünk abban az esetben, ha a lokális viszonyokon átívelő kommunikációt biztosítani hivatott médiumokkal kapcsolatban nincs minimális konszenzus sem a cselekvők között. Az ilyen hálózatok az integráció diszfunkcióinak állandósulását fejezik ki: megbízható mediatizált kommunikációs csatornák hiányában a másikba vetett bizalom megrendül, összességében dezintegrációt eredményezve. „Konzervatív alrendszereknek” tekinthetők azok a hálózatok, ahol a környezeti visszacsatolás során kizárólag azok az információk kerülnek kiválasztásra, melyek harmóniáról tanúskodnak. Minthogy az ilyen hálózatokban a környezeti diszfunkciók vakfoltban maradnak, az adaptáció óhatatlanul torzul, egy öszszességében konzervatív múködésmódot eredményezve. „Technokrata alrendszerről” beszélhetünk abban az esetben, ha azonosíthatók olyan visszacsatolási mechanizmusok, melyek a társadalmi patológiákra diszfunkciókként tekintenek. Ebben az esetben a torzulások korrekciójára az alrendszerek adaptációjának és hatékonyságának növelése révén nyílik lehetőség, kifejezve a társadalmi felelősségvállalás rendszerszerü modelljét.

A - lashi értelemben vett - információs hálózatokban a szolidaritás kérdése a tömegkommunikációs csatornákon valós időben terjedő ingerek szintjén értelmezhető. „Kontrollálhatatlan információáramlásról” beszélhetünk abban az esetben, ha a cselekvők lemondani kényszerülnek a narratív értelemképződés lehetőségéről, és megadják magukat a szüntelenül érkező, fragmentált jelentések áradatának. Amennyiben az információ eldologiasító hatásától senki és semmi sem védi meg a cselekvőt, az értelemadás hiánya fokozatosan az önmagához és másikhoz való viszony természetes velejárója lesz. „Privát virtuális valóságként” értelmezhetők azok a konstellációk, melyek célja az, hogy a cselekvők visszahúzódhassanak az interakciók során közösen konstruált valóságból. Az ilyen szigetszerû zárványokban egy védett privát tér védelmében feláldozásra kerül a kollektív nyilvánosság, és az eszképizmus lép a társakhoz

10 Példaként olyan helyzetekre utalhatunk, ahol a segítő és segített között áthidalhatatlan hatalmi különbségek vannak, aminek következtében a rászoruló óhatatlanul passzív szerepbe kerül (pl. határon túli magyarokra irányuló segítés: Zakariás 2016). 
való kapcsolódás helyére. „Alternatív virtuális valóságról” beszélhetünk akkor, ha az információs hálózatok olyan párhuzamos valósághoz kínálnak hozzáférést, amely mentes az eredetiekben megjelenő szenvedéstől. Az ilyen hálózatokban a gyorsan és korlátlanul hozzáférhető kollektív tudás eldologiasítás helyett emancipatorikus szerepet tölt be.

Az esztétikai reflexivitás hálózataiban a szolidaritás az autentikus lét védelme kapcsán ragadható meg. „Pária reflexivitásról” beszélhetünk abban az esetben, ha az autonóm értelemképződés ára a társakról való lekapcsolódás. Az ilyen hálózatokban az egyéni valóságkonstrukció torzulásaival magukra maradnak a cselekvők, aminek következtében a társaktól való totális függés és tökéletes lekapcsolódás esélye egyaránt megnő. „Szolipszista reflexió” figyelhető meg azokban a hálózatokban, ahol az autonóm értelemképződés steril formája jön létre, melynek horizontján csak a saját problémák jelenhetnek meg. A tematikusan beszúkült, kizárólag az énre korlátozódó valóságkonstrukció kitakarja a másik problémahorizontját, így az esetleges segítésre irányuló törekvések is óhatatlanul félrecsúsznak. „Szubjektiváló reflexivitás” jellemzi azokat a hálózatokat, ahol a társadalmi eredetű szenvedések enyhítésének kulcsa a társadalmi jelentéshorizontról való lekapcsolódás. Az ilyen konstellációkban a társadalmi felelősségvállalás kiterjed arra is, hogy teret biztosítson a személyes identitás konstrukciójához, akár a társakhoz való igazodás csökkenése árán is támogatva az egyént autonómiatörekvéseiben.

$\mathrm{Az}$ épített technikai környezet hálózataiban a szolidaritás a materiális kényszerstruktúra szintjén ragadható meg. „Posztapokaliptikus környezetrő” beszélhetünk akkor, ha irreverzibilis beavatkozások eredményeként a társadalmilag formált világ élhetetlenné válik. Az ilyen konstellációk a materiális világ demokratikus eljárások révén kontrollált társadalmasításának kudarcára utalnak, kifejezve a társadalmi felelősségvállalás természeti dimenzióját. „Fényűző környezet” jellemzi azokat a hálózatokat, ahol a materiális környezettel összefüggő pozitív élmények exkluzívakká válnak. Az ilyen konstellációkban a torzult hálózatok által egyébként sem érintett cselekvők komfortja - a szenvedés csökkentése helyett - a fényüzés kifejeződésévé válik. „Ökotudatos környezetről” beszélhetünk akkor, ha a technikai-tárgyi hálózatok a szolidaritás ökológiai koncepciójára utalnak. E konstellációkban a patológiák okaként a materiális környezet nivelláló vagy egészségtelen jellege jelenik meg, amelynek ellensúlyozási eszköze a technikai és környezeti ártalmak csökkentése lesz.

A fenti ideáltipikus hálózati konstellációkat az alábbi táblázat foglalja össze: 
2. táblázat: A hiányzó, diszfunkcionális kiüresedett és hálózati szolidaritás kötései

\begin{tabular}{|c|c|c|c|c|}
\hline & & preintencionális & intencionális & posztintencionális \\
\hline \multirow{4}{*}{ hiányzó szolidaritás } & $\begin{array}{l}\text { egyenlőtlenségi } \\
\text { hálózatok }\end{array}$ & $\begin{array}{l}\text { könyörtelen } \\
\text { habitus }\end{array}$ & neoliberális illúzió & $\begin{array}{l}\text { kontrollálatlan } \\
\text { mező }\end{array}$ \\
\hline & reflexív hálózatok & feladott rutinok & $\begin{array}{l}\text { hitelvesztett } \\
\text { reflexivitás }\end{array}$ & $\begin{array}{l}\text { bemerevedett } \\
\text { intézmény }\end{array}$ \\
\hline & $\begin{array}{l}\text { kommunikációs } \\
\text { hálózatok }\end{array}$ & $\begin{array}{l}\text { fragmentált } \\
\text { életvilág }\end{array}$ & $\begin{array}{l}\text { kiüresedett } \\
\text { kommunikáció }\end{array}$ & $\begin{array}{l}\text { le nem horgonyzott } \\
\text { alrendszer }\end{array}$ \\
\hline & $\begin{array}{l}\text { technikai } \\
\text { hálózatok }\end{array}$ & $\begin{array}{l}\text { kontrollálhatatlan } \\
\text { információáramlás }\end{array}$ & pária reflexivitás & $\begin{array}{l}\text { posztapokaliptikus } \\
\text { környezet }\end{array}$ \\
\hline \multirow{4}{*}{$\begin{array}{l}\text { diszfunkcionális } \\
\text { szolidaritás }\end{array}$} & $\begin{array}{l}\text { egyenlőtlenségi } \\
\text { hálózatok }\end{array}$ & öncélú habitus & idealizáló illúzió & elleplező mező \\
\hline & reflexív hálózatok & izolált rítusok & $\begin{array}{l}\text { valóságidegen } \\
\text { szakértői } \\
\text { reflexivitás }\end{array}$ & $\begin{array}{l}\text { tudományos } \\
\text { intézmény }\end{array}$ \\
\hline & $\begin{array}{l}\text { kommunikációs } \\
\text { hálózatok }\end{array}$ & kizáró életvilág & $\begin{array}{l}\text { illedelmes } \\
\text { kommunikáció }\end{array}$ & $\begin{array}{l}\text { konzervatív } \\
\text { alrendszer }\end{array}$ \\
\hline & $\begin{array}{l}\text { technikai } \\
\text { hálózatok }\end{array}$ & $\begin{array}{l}\text { privát virtuális } \\
\text { valóság }\end{array}$ & \begin{tabular}{|l} 
szolipszista \\
reflexió
\end{tabular} & $\begin{array}{l}\text { fényűző technikai- } \\
\text { épített környezet }\end{array}$ \\
\hline \multirow{4}{*}{ hálózati szolidaritás } & $\begin{array}{l}\text { egyenlőtlenségi } \\
\text { hálózatok }\end{array}$ & sportszerü habitus & teodícea illúzió & redisztributív mező \\
\hline & reflexív hálózatok & $\begin{array}{l}\text { tradicionalista } \\
\text { rutinok }\end{array}$ & szcientista reflexió & $\begin{array}{l}\text { reszponzív } \\
\text { intézmény }\end{array}$ \\
\hline & $\begin{array}{l}\text { kommunikációs } \\
\text { hálózatok }\end{array}$ & $\begin{array}{l}\text { kisközösségi } \\
\text { életvilág }\end{array}$ & $\begin{array}{l}\text { demokratikus } \\
\text { kommunikáció }\end{array}$ & $\begin{array}{l}\text { technokrata } \\
\text { alrendszer }\end{array}$ \\
\hline & $\begin{array}{l}\text { technikai } \\
\text { hálózatok }\end{array}$ & $\begin{array}{l}\text { alternatív virtuális } \\
\text { valóság }\end{array}$ & $\begin{array}{l}\text { szubjektiváló } \\
\text { reflexivitás }\end{array}$ & $\begin{array}{l}\text { ökotudatos } \\
\text { technikai-tárgyi } \\
\text { környezet }\end{array}$ \\
\hline
\end{tabular}

A fenti esetek egyrészt a szolidaritás meggyengülésének különböző dimenzióit jelenítik meg. Olyan területekre utalnak, amelyekről a társadalom kivonul: ezek diszfunkciója esetén a társak nem adnak segítséget, más szóval e kockázatokért és problémákért a társadalom nem vállal felelősséget. Másrészt azt fejezik ki, hogy milyen következményei vannak annak, ha a kvázi-terápiás kötések zárványai jönnek létre. Ahogy a segítéspotenciállal jellemezhető kapcsolódások eloldódnak a tényleges szenvedésektôl, úgy ürülnek ki értelmileg, ami egyúttal meg is változtatja őket. A kiaknázatlanul maradó terápiás hatás következtében a hálózat horizontjáról fokozatosan eltűnik a segítés lehetősége, és természetessé válik az öncélúság. A kvázi-terápiás hálózatok inadekvát kapcsolódása ilyenformán egyszerre erősíti fel a közöny, az elkülönülés (szegregáció) és egy szenvedésmentes privát valóságba való visszavonulás tendenciáit (eszképizmus). Miközben a magára maradó szenvedés tapasztalatai a szolidaritás meggyengülését eredményezik, a segítés zárványban megrekedt hálózatai pedig a szolidaritás értelmi kiüresedéséhez, inadekváttá válásához vezetnek, a torzult és kvázi-terápiás hálózatok egymáshoz kapcsolódásában a szolidaritás új formái számára nyílik tér. Az alábbiakban e fogalmi háló alapján újraértelmezve Castells és Castel műveit, arra teszek kísérletet, hogy bemutassam a szolidaritás késő modern hálózati paradigmájának sajátosságait, felvillantva a premodern és klasszikus modernitásbeli mintázatoktól való különbségeket. 


\section{A szolidaritás változó paradigmái}

Ahogy azt Castel részletesen bemutatja, a premodern társadalmak szolidaritási paradigmáját mindenekelőtt egyfajta primer szociabilitás jellemzi, ami a faluközösségen és a hủbéri láncon belüli pozíciók által meghatározott hierarchizált gondoskodási viszonyokon alapult. Azoknak, akik a szolidaritás e formáján kívül rekedtek, a csavargás hatósági üldözésével és szankcióival kellett szembenézniük. E konstellációban kirajzolódó szolidaritási paradigmát a különböző integrációs szinteken azonosított hiányzó, értelmileg kiüresedett és adekvát segítési hálózatok együttesen jelölik ki. A preintencionális hálózatok szintjén a kisközösségi életvilág és tradicionalista rutinok alapozzák meg a szolidaritás kereteit abban az értelemben, hogy meghatározzák a rászorultság közösen kialakított, magától értetődő értelmezési sémáit (pl. ki a beteg, az éhező?), továbbá kijelölik azokat a repetitív technikákat, melyek a szenvedéseket hivatottak kezelni (pl. milyen rutinok szerint kell berendezni a napokat, hogy ezeket elkerülje az ember?). Az intencionális hálózatok szintjén a - keresztény világnézet formáját öltő - teodícia illúziója kínál olyan átfogó értelmezési keretet, melyben a szenvedéseknek értelem adható (pl. szenvedés mint próbatétel), a segítés morális kötelességei meghatározhatók (pl. segíts felebarátodon), és végső soron a fennálló társadalmi berendezkedés (pl. az e világi szenvedés jelentéktelen az üdvözüléshez képest) legitimálható. A posztintencionális hálózatok szintjén olyan redisztributív mezólogikát találunk, amely nem univerzális igazságossági, hanem elsősorban rendi, másodsorban pedig - a lokális szokásokon, valamint a domináns pozíciókban lévők személyes döntésein alapuló - rászorultsági szempontok szerint osztja el újra a megtermelt értékeket.

A premodern szolidaritási paradigma hiányai elsősorban a fenti teljesítményekkel összefüggésben értelmezhetők, amennyiben a közösségi szolidaritás korlátaiból fakadnak. A preintencionális hálózatok szintjén a könyörtelen habitus említhető meg, ami az univerzális emberi méltóság koncepciójának hiányából fakadóan mindazokra kiterjedt, akik kívül rekedtek a közösségi szolidaritási hálón (pl. csavargó), illetve valóságértelmezésen (pl. nem keresztények). Az intencionális hálózatok szintjén a hitelvesztett és páriareflexivitás említhető meg: míg az előbbi a teodícea illúzió által háttérbe szorított racionális ismeretek relevanciájának és hatásának korlátaira, addig az utóbbi a kollektív reprezentációktól való eltérés közösségi szankcióira utal. Posztintencionális szinten az intézmények merevsége és a jogbiztonság megrendülése határozza meg a legfontosabb szolidaritási hiányokat: ehhez szükséges ismeretek, motiváció és szakosodott intézmények hiányában a premodern társadalmi struktúrák csak lassú átalakulásra voltak képesek, miközben a rendszerszerü jog minimális szintjét is csak kevesek számára biztosították.

A szolidaritás diszfunkcionális hálózatai, a hiányokhoz hasonlóan, szintén a szokások, értelmezések és intézmények vakfoltjai felől értelmezhetők. A preintencionális hálózatok szintjén az öncélú habitusok és a kizáró életvilágok fejezik ki a felelősségvállalás korlátait. Minthogy a társadalmi játszmák a rendi logika kötött, egydimenziós 
hatalmi terében zajlanak, így végső soron a segítési kísérletek sem tudnak kitörni annak keretei közül, végső soron újratermelve a belőle fakadó problémákat. Hasonlóképpen, abból fakadóan, hogy a valóság evidens értelmezése az együtt élők közösségére korlátozódik, annak a lehetôsége, hogy az alternatív életvilágba beágyazott másikon segítsen valaki, minimális marad. Az intencionális hálózatok szintjén az idealizáló illúziók jelölik ki a félrecsúszott segítési kísérletek csapdáit. Közvetlen kommunikáció, valamint szisztematikus reflexió híján a szenvedésről legfeljebb olyan kép alkotható, amely valamilyen előzetes értékválasztás kereteibe illeszkedik, ez pedig többnyire nem alkalmas a tényleges szenvedések enyhítésére. A posztintencionális hálózatok szintjén az elleplező mezők és a fényüző környezet említhetők meg. A hatalmi viszonyok naturalizálása és a környezet luxusszempontok szerinti fejlesztése, különbözőképpen bár, de egyaránt olyan struktúrákra utalnak, ahol a privilegizált társadalmi csoportok érdekei érvényesülnek - az alárendelt rétegek kárára.

A klasszikus modernitás szolidaritási paradigmája egyrészt a premodernitás kezeletlen és inadekvát módon kezelt szenvedéseire kidolgozott válaszokkal jellemezhető, másrészt azokkal az újfajta hiányokkal és diszfunkciókkal hozható összefüggésbe, melyek keretei között bukkantak fel, nem függetlenül a premodern segítési formák meggyengülésétől. Castel elemzései nem csak azt mutatják be, hogy a bérmunkán alapuló társadalombiztosítási rendszer milyen problémákat kezelni próbálva alakult ki, hanem azt is, hogy milyen pontokon tekinthető sérülékenynek. A klasszikus modernitás legfontosabb újítása a premodern és kora modernitásbeli szolidaritáshoz képest az, hogy az állam főszereplővé lép elő a munkaerőpiaci kockázatok kezelésében, és ennek megfelelően a társadalmi felelősségvállalás a jog területére tevődik át. Ilyenformán a társaktól való függőségi viszony, a rászorultság és a segítés adekvát formái megszűnnek a szokások vagy helyi hierarchiák előzetes szerkezetéhez igazodni. Ehelyett olyan általános szinten szabályozott szerződéses viszonyokká válnak, melyek keretei a mindenkori politikai küzdelmekben formálódnak. A klasszikus modernitás szolidaritási paradigmájának további sajátossága, hogy a társadalmi felelősségvállalás azokra terjed ki, akik jövedelmük egy részével hozzájárulnak a biztosítási rendszerhez. A segítségnyújtás domináns formája a különböző szakértői tudásokra támaszkodott intézményrendszer, mely saját szempontjai alapján határozza meg a rászorulók körét és a szenvedés csökkentésének adekvát eszközeit.

E keretek között a torzult és kvázi-terápiás hálózatok összekapcsolódásáért szakértői aktorok által tervezett mechanizmusok felelősek, a lokális viszonyokon átívelő struktúrákat hozva létre. A preintencionális hálózatok szintjén a klasszikus modernitás központi dimenziójaként értelmezhető kapitalizmus versenyszellemének kifejeződését, a sportszerü habitust említhetjük meg. Minthogy e szolidaritási paradigma egy a versengés keretei között szerveződő társadalmi konstellációra adott válaszként jött létre, így a - többnyire rivalizálások okán keletkező - torzulások kezelésének egyik fő eszközeként is a küzdelmek fair mivoltának - egyének szintjén történő - biztosítása jelölhető meg. Az intencionális hálózatok szintjén a szcientista reflexió és a demokratikus kommunikáció 
emelhető ki. Az előbbi, a tudományos világkép diadalát kifejezve, arra a lehetőségre mutat, hogy az előítéletek és dogmatikus feltételezések helyett egy torzítatlan megismerési folyamatban feltáruló tudás szolgáljon a szenvedések csökkentésének alapjaként. Az utóbbi pedig a személyközi viszonyok - univerzális emberi méltóság eszméjéből következő - formájának lehetőségére utal. A posztintencionális szintű hálózatok között a redisztributív mezô és a technokrata alrendszer jelentősége hangsúlyozható. A klasszikus modernitás szolidaritási paradigmája fundamentális szinten az újraelosztásról szól, amennyiben a kapitalista termelési viszonyok negatív következményei csak ily módon tarthatók kordában. Ennek kereteit a társadalom egészét meghatározó mediatizált alrendszerek (pl. a folyamatosan fejlődő jogszabályok) biztosítják.

A társadalmi felelősségvállalás e mintázatából következő hiányok preintencionális szintjén a könyörtelen habitust és az életvilág fragmentálódását említhetjük. Míg a premodern időszakban a könyörtelenség elsősorban a lokális közösségen kívüliekre, valamint az esszenciálisan másnak minősülőkre vonatkozott, addig a klasszikus modernitásban a kapitalista piaci verseny következményeként ez általános sajátossággá vált. A funkcionális differenciálódás és a tradíciókritika hatására emellett a közös magától értetődő jelentések eróziója vált alaptapasztalattá. Intencionális szinten e folyamatokat kiegészítette a neoliberális illúzió veszélye, ami a piaci logika korlátlan és kritikátlan érvényesítésére utal az élet minden területén. A posztintencionális hálózatok között a kontrollálatlan mező és a posztapokaliptikus környezet emelhető ki. Előbbi a tôkefelhalmozás logikájának totalizálódásával összefüggő társadalmi egyenlőtlenségek korlátlan növekedésében, utóbbi pedig a környezeti erőforrások irreverzibilis kimerítésével szembeni közönyben fejeződik ki.

A szolidaritás diszfunkcióinak preintencionális szintjén az izolált rutinokat említhetjük: minthogy a rendszerek által közvetített instrumentális racionalitás áthatja a hétköznapi élet nagy részét, az egyénileg formált szokások csupán egy szúk térben fejthetik ki hatásukat. Intencionális szinten a valóságidegen szakértői reflexió jelentősége nő meg. Ahogy a vallási világkép helyét átveszi a tudományos, úgy válik olyan tekintélyi figurává a szakértő, akinek valóságértelmezése a laikusok szempontjai alapján nem bírálható. Ennek hatására fokozatosan eltávolodik azoktól a tapasztalatoktól, melyekre vonatkozik, végső soron irrelevánssá válva azok számára. Posztintencionális szinten tudományos intézményeket és konzervatív alrendszereket találunk. Ahogy a szolidaritás aktorai szakértői intézmények lesznek, úgy megnő az esélye annak, hogy a segítésnyújtás szempontjait felülírják a szakértelem növelésének szempontjai - végső soron a megismeréshez képest háttérbe szorítva a szenvedés enyhítésének célját. Az ész nevében kiépülő klasszikus modernitásbeli alrendszerek abban az értelemben önigazolási potenciállal bírnak, hogy saját eredményeiket hangsúlyozzák az esetleges nem szándékolt negatív következményekkel szemben. Ilyenformán - a haladás illúzióját fenntartva - saját privilegizált pozíciójukat naturalizálják.

A késő modernitás szolidaritási paradigmája elsősorban a klasszikus modernitás inadekváttá váló segítési válaszainak korrekciójaként értelmezhető. Ahogy már Castel 
elemzéseiből is kiderül, a szolidaritás bérmunkán alapuló társadalombiztosítási modellje súlyos külső kihívásokkal néz szembe. A gazdasági növekedés megtorpanása, a válságok és a dekonjunktúra következtében megugró munkanélküliség egyaránt azzal fenyeget, hogy finanszírozhatatlanná válik a rendszer. Castells elemzései ezt kiegészítik abból a szempontból, hogy rámutatnak, a globális információs társadalom kialakulását követően nem csupán esetleges külsődleges kihívásokkal, hanem a szolidaritási paradigma lényegét érintő paradoxonokkal kell számolnunk. A bérmunkajárulékokkal finanszírozott biztosítási rendszer a munka kiszámíthatatlanná válásával megszűnik stabil forrásként működni; a jóléti államok mozgástere beszűkül; a jóléti társadalompolitika globális piaci hátránnyá válik; a politikai nyilvánosság pedig elveszti érdekegyeztető képességét. Mindez együttesen arra utal, hogy a szolidaritás klasszikus modernitásbeli paradigmája fenntarthatatlan - a kérdés csak az, hogy milyen irányba alakul át.

Castells alapján ebből a szempontból három lehetőséget azonosíthatunk: szolidaritási vákuum alakul ki (pl. egyenlőtlenségek növekedése, fekete lyukak keletkezése), regresszív válaszok (pl. fundamentalista, nacionalista identitások) születnek, vagy a hálózati logika keretei között újrafogalmazódnak a rászorultság és felelősségvállalás keretei (pl. környezetvédelmi, feminista, globalizációkritikai mozgalmak, progreszszív szociálpolitika). Ilyenformán a késő modernitás szolidaritási paradigmája nem tekinthető kiforrott, szokások, szemantikák és intézmények által stabilizált mintázatnak. Sokkal inkább úgy tekinthetünk rá, mint a klasszikus modernitás problémái mellett - részben annak nem szándékolt következményeként előálló - új kihívásokkal is küzdő, folyamatos alakulásban lévő konstellációra. Valamely meghatározott mintázatot kikényszerítő „társadalmi tények” hiányában ugyanakkor korántsem tűnik el a szolidaritás, csupán flexibilis és egyúttal kevésbé kiszámítható formában működik tovább. Ez azt jelenti, hogy szenvedéstapasztalatok és segítési mechanizmusok általános szervezőelv nélkül, ad hoc módon kapcsolódnak egymáshoz, egyaránt magukban hordozva a szenvedésre adott adekvát és inadekvát válaszok lehetőségét. Bizonyos értelemben a késő modernitás szolidaritási paradigmája nem más, mint egy forrongási állapot állandósulása: ahogy a késő modernitás meghatározó kényszerévé a flexibilitás válik, úgy lesz a társakra való ráutaltság és felelősségvállalás is kiszámíthatatlan, amit leginkább a gyors átalakulás lehetőségét biztosító hálózati logika képes kezelni.

A hálózati szolidaritás a sematikusnak, valóságidegennek, konzervatívnak és saját tudományos képessége tekintetében elbizakodottnak bizonyuló segítési mechanizmusok helyett egy empatikus, individualista, reszponzív modellt ajánl (vö. információs termelési mód, hálózati szerveződés). Egyelőre azonban az is világos, hogy ez a modell nem képes arra, hogy a klasszikus modernitás alapkonfliktusára megoldást kínáljon: a felszámolt közösségi szolidaritási háló által hagyott ûrt az interaktív intézmények is csak részben képesek betölteni, miközben az egyenlőtlenség további fokozódását eredményezik (vö. globális hálózatok hatása a lokális gazdaságra). Ráadásul a klasszikus modernitás problémáinak kezelésére tett kísérlet a valóság szcientista ér- 
telmezésének megkérdőjelezését vonta magával, aminek következtében a problémák új osztálya jött létre: elemi szinten váltak bizonytalanná a valóságértelmezés és megbecsülés keretei, összességében a valóság értelmezhetőségéről való lemondást eredményezve (vö. regresszív identitásmintázatok, demokrácia válsága). Ebben a konstellációban felerősödik a felemás sikerekkel kecsegtető eszképizmus: az információs társadalom lehetőséget teremt egy virtuális valóság zárványába való visszahúzódásra, ami egyúttal a segítési relációk inadekvát formáinak expanziójával is fenyeget a rítusok, párkapcsolatok, játszmák és interakciók izolált, öncélú mechanizmusai formájában (vö. valós virtualitás kultúrája).

Mindezek alapján a késő modernitás szolidaritási paradigmájára egy belső feszültségekkel terhelt konstellációként tekinthetünk. Egyrészt - állami szakértői rendszerek által múködtetett - általános mechanizmusok hiányában a rászorultság és segítés rendszerszerű koordinációjától megfigyelhető egyfajta visszalépés a szenvedés tapasztalatai köré szerveződő közösségekhez. Másrészt ezek a közösségek - élve az információs hálózati társadalom nyújtotta lehetőségekkel - korántsem támaszkodnak térben és időben kötött interakciós relációkra. Ehelyett a lokalitásoktól függetlenül szerveződnek, a folyamatosan változó igényekhez igazítva kiterjedésüket és szerkezetüket. Ilyenformán a hálózati logika, ha tartalmi szinten nem is képes a szolidaritás stabil kereteit megteremteni, mégis olyan formává válik, amely flexibilitása révén választ kínál a késő modernitás legfontosabb kihívására: a kockázatok és a kontingenciák kontrollálhatatlanná válására. Természetesen a késő modernitás hálózati paradigmája amellett, hogy megoldásokat kínál, egyúttal sajátos patológiákat is kitermel, melyekkel együtt jellemezhető múködése.

A torzult és kvázi-terápiás hálózatok egymáshoz kapcsolódásának bonyolult feladatát a preintencionális hálózatok közül az alternatív virtuális valóságok képesek jó eséllyel kezelni, melyek a nyilvánosság keretei között biztosítják annak a lehetőségét, hogy a korlátlanul áramló információból a saját igényeinek megfelelő mintázatot állítson össze az egyén, felülemelkedve annak kontrollálhatatlanságán. Az intencionális hálózatok szintjén a szubjektiváló reflexió tekinthető hangsúlyosnak a késő modern szolidaritás megalapozásában. E hálózatok kiterjesztik a szolidaritás fogalmát az autentikus lét irányába, és ezáltal közvetlen kapcsolódási pontot kínálnak az individuális szenvedéstapasztalatokon alapuló közösségek számára. A posztintencionális hálózatok szintjén a reszponzív intézmények és az ökotudatos környezet emelhetők ki. Előbbi a szolidaritást múködtető szervezetek múködési mechanizmusaiba emeli be azt a szempontot, hogy a hozzá forduló cselekvőkhöz egyediségükben kell viszonyulni. Utóbbi pedig a természeti, materiális környezettel kapcsolatban veti fel a fenntarthatóság kérdését.

A fenti teljesítmények vakfoltjaiban találhatók azok a hiányok, melyek a szolidaritási háló lyukaira utalnak. A preintencionális hálózatokban a feladott rutinok és a kontrollálhatatlan információáradat emelhető ki. A flexibilitás imperatívuszával jellemezhető globális piacgazdaság potenciális következménye, hogy a repetitív visel- 
kedésminták tere minimálisra csökken, elemi ontológiai bizonytalansággal terhelve meg az egyént. Mindezt a nyilvános valóságkonstrukció szintjén kiegészíti a kezelhetetlen tömegú információ, melynek elemei - minthogy nem formálhatók értelmes történetekké - értelmi kiüresedéshez vezetnek. Intencionális szinten a neoliberális illúzió, hitelvesztett reflexivitás és kiüresedett kommunikáció hálózatai fejezik ki, milyen következményei vannak a magukban álló torzulásoknak. A piaci logika totalizálódása, a racionalitásba vetett hit megingásával és kommunikációképtelenséggel párosulva, egy olyan kaotikus világlátáshoz vezet, melyben orientációs pontok nélkül maradnak a cselekvők. Ilyenek hiányában pedig a legitim, uralmi típusú kapcsolatokkal szemben megnő a hatalmi relációk valószínűsége, összességében egy konfliktusokkal terhelt konstellációt eredményezve. A posztintencionális hálózatok szintjén kontrollálatlan mezők, le nem horgonyzott alrendszerek és posztapokaliptikus környezet együttesével számolhatunk. Noha a jóléti nemzetállamok valamiféle korlátot állítanak az egyenlőtlenségek növekedése elé, globális szinten ilyen hatásokról nem beszélhetünk. A kulturális globalizáció fragmentáló hatásának következményeként azok az életvilágbeli előfeltételek, melyekre a mediatizált kommunikáció alrendszerei támaszkodnak, nem adottak többé, végső soron veszélyeztetve a működésüket. Mindezek következtében ellehetetlenülnek az olyan kezdeményezések, melyek a környezet korlátlan kizsákmányolása elé próbálnak akadályokat gördíteni.

A késő modernitásbeli hálózati szolidaritás diszfunkcióinak preintencionális szintjén a kizáró életvilágot és a privát virtuális valóságot találjuk. Noha az előbbi nem térbeli lokalitások, hanem hálózati zárványok keretében konstruálódik, hatásában mégis ahhoz hasonló: a valóság értelmezésének a hálózaton kívüliek számára értelmezhetetlen formáját hozza létre. Az utóbbi esetben a szolidaritási viszonyok félrecsúszása a társaktól való totális függetlenedésből fakad: ha egy információs hálózat miatt kommunikációképtelen cselekvőperspektíva alakul ki, annak eredményeként a másikhoz való odafordulás ellehetetlenül. Az intencionális hálózatok szintjén az idealizáló illúziókat, az illedelmes kommunikációt és a szolipszista reflexiót emelhetjük ki. Ezeket az köti össze, hogy különbözőképpen, de egyaránt közönyt fejeznek ki: a legitimitás prekoncepciókhoz kötése, a pszeudokommunikáció és a kizárólag befelé forduló reflexió mind arra utal, hogy a másik felé fordulás legfeljebb látszólagos. Tényleges tapasztalatok és interakciók helyett valójában saját előfeltételezéseinek foglyaként jár el a cselekvő, és ezáltal elmulasztja a tényleges segítségnyújtás lehetőségét. A posztintencionális hálózatok szintjén a fényűző környezet emelhető ki: ahogy kimerülnek az értelemadás tradicionális és klasszikus modernitásbeli forrásai, úgy marad a fogyasztás imperatívusza az egyetlen alternatíva, aminek következménye a materiális környezet expanziója és esztétizálódása. 
3. táblázat: A premodern, klasszikus és késő modern szolidaritás ideáltipikus mintázatai

\begin{tabular}{|c|c|c|c|}
\hline & adekvát segítés & kezeletlen szenvedések & inadekvát segítés \\
\hline premodernitás & $\begin{array}{l}\text { tradicionalista rutinok, } \\
\text { kisközösségi életvilág, } \\
\text { teodíceai illúzió, } \\
\text { redisztributív mező }\end{array}$ & $\begin{array}{l}\text { könyörtelen habitus, } \\
\text { hitelvesztett és } \\
\text { páriareflexivitás, } \\
\text { intézmények merevsége }\end{array}$ & $\begin{array}{l}\text { öncélú habitusok, kizáró } \\
\text { életvilágok, idealizáló } \\
\text { illúziók, elleplező mezők, } \\
\text { fényűző környezet }\end{array}$ \\
\hline $\begin{array}{l}\text { klasszikus } \\
\text { modernitás }\end{array}$ & $\begin{array}{l}\text { sportszerű habitus, } \\
\text { szcientista reflexió, } \\
\text { demokratikus } \\
\text { kommunikáció, } \\
\text { redisztributív mező, } \\
\text { technokrata alrendszer }\end{array}$ & $\begin{array}{l}\text { könyörtelen habitus, } \\
\text { életvilág fragmentálódása, } \\
\text { neoliberális illúzió, } \\
\text { kontrollálatlan mező, } \\
\text { posztapokaliptikus } \\
\text { környezet }\end{array}$ & $\begin{array}{l}\text { izolált rutinok, } \\
\text { valóságidegen szakértői } \\
\text { reflexió, tudományos } \\
\text { intézmények, konzervatív } \\
\text { alrendszerek }\end{array}$ \\
\hline késő modernitás & $\begin{array}{l}\text { alternatív virtuális } \\
\text { valóságok, szubjektiváló } \\
\text { reflexió, reszponzív } \\
\text { intézmények, ökotudatos } \\
\text { környezet }\end{array}$ & $\begin{array}{l}\text { feladott rutinok, } \\
\text { kontrollálhatatlan } \\
\text { információáradat, } \\
\text { neoliberális illúzió, } \\
\text { hitelvesztett } \\
\text { reflexivitás, kiüresedett } \\
\text { kommunikáció, } \\
\text { kontrollálatlan mezők, } \\
\text { le nem horgonyzott } \\
\text { alrendszerek, poszt- } \\
\text { apokaliptikus környezet }\end{array}$ & $\begin{array}{l}\text { kizáró életvilág, } \\
\text { eszképista intimitás, } \\
\text { privát virtuális valóság, } \\
\text { idealizáló illúziók, } \\
\text { illedelmes kommunikáció, } \\
\text { szolipszista reflexió, } \\
\text { fényűző környezet }\end{array}$ \\
\hline
\end{tabular}

Ahogy a fenti áttekintésből jól látható, a szolidaritás premodern, klasszikus és késő modern paradigmái a társadalmi segítségnyújtás múködő formáinak, valamint a kezeletlen és a félrekezelt szenvedéseknek az eltérő mintázataival jellemezhetők. ${ }^{11}$ A premodern korszak egyfelől megbízható, ugyanakkor helyhez és függőségi viszonyokhoz kötött felelősségközösségekkel jellemezhető, melyek hatékonyságának gátat szab a segítéshez kapcsolódó reflexivitás korlátozott mivolta. Az e korlátok meghaladása által motivált klasszikus modernitás szolidaritási paradigmája ezzel szemben kiszámítható, a lokalitástól független jogi státuszhoz kötött és racionális, ugyanakkor - épp formalizáló jellegéből fakadóan - a keretein kívül rekedők, valamint az egyéni szenvedések specifikumai iránt érzéketlen. Az e paradigmát múködtető intézmények eróziójával, illetve a diszfunkciók azonosításával párhuzamosan rajzolódnak ki a késő modernitás sajátosságai. A segítés és rászorultság olyan kapcsolódásai jönnek létre, melyek egyrészt a szenvedések tapasztalatai köré szerveződnek, ugyanakkor nem közösségi, hanem a lokalitástól eloldott formában; másrészt hálózatos jellegükből fakadóan flexibilisek, ugyanakkor esetlegesek és kiszámíthatatlanok; harmadrészt szakértői tudásokra építenek, ugyanakkor az értelemvesztés, a defetizmus és az eszképizmus veszélyét hordozzák magukban.

A késő modernitás hálózati szolidaritásának szerveződésében ilyenformán kitüntetett szerepet játszanak a társadalmi okokra visszavezethető hasonló szenvedéstapasztalatok. Jobb híján potenciálisan ezek képesek a hiányzó lokális társulások és

11 Korábban is igyekeztem amellett érvelni, hogy a modernitás szakaszainak sajátosságai soha nem múlnak el az új integrációs logikák megjelenése következtében, hanem sokkal inkább rárétegződnek azokra (Sik 2015a). Jelen vizsgálódások során ezt azzal egészíthetjük ki, hogy a szolidaritás különböző paradigmái sem totálisan jellemeznek egy társadalmat: eltérő hálózatokban vegyes típusaik képzelhetők el. 
szakértői intézmények helyett olyan keretként szolgálni, melyre támaszkodva felelősségközösségek alakulhatnak ki. A szenvedés különböző integrációs szintű hálózati torzulásokból fakadó formáiról belátható (Sik 2015b), hogy nem redukálhatók semelyik hálózatszervezési logika szerinti pozícióra (így a különböző tőkékkel való ellátottságra vagy valamilyen élményközösségre sem). Ebből fakadóan a hasonló szenvedésmintázatok magukban rejtik a lehetőségét a strukturális és kulturális különbségek meghaladásának: teljesen eltérő társadalmi pozícióban lévők között azonosulási pontot teremthet, ha a szenvedés hasonló mintázatáról rendelkeznek tapasztalatokkal. ${ }^{12}$ A hasonló szenvedéstapasztalatok alapján szerveződő hálózatokban továbbá kivételes lehetőség nyílik a közös értelem megszületésére: a másikkal való azonosulás morális hasadásélményhez vezethet, esélyt teremtve a felelősség és a bizalom új formáinak megalapozására.

A szenvedés határállapotainak közös tapasztalata ilyenformán egyszerre motivál az eszképizmus feladására, teremt kapcsolódási pontot különböző társadalmi pozíciók között és kínál fel újfajta morális értelmezéseket. A szolidaritás e jellegzetesen késő modern forrása a szenvedés határállapotaiban rejlő identifikációs potenciálból fakad: minthogy az azonosulást immár nem képes biztosítani sem a közös életforma és a tényleges személyközi interakció (vö. Durkheim „mechanikus szolidaritása”), sem pedig a munkamegosztási rendszer szcientista világképe és az egymásra utaltság élménye (vö. Durkheim „organikus szolidaritása”), így az egyénileg átélt patológiák primer tapasztalati bázisa szolgálhat társadalmi csoportokon átívelő azonosulási pontként. Adott hálózati konstellációban átélt szenvedési határállapot magában rejti annak lehetőségét, hogy más integrációs sajátosságú hálózatban átélt azonos jellegű szenvedéssel azonosulni tudjon az egyén. ${ }^{13}$

Az individuális szenvedések dekontextualizált csomópontjai közti kötések a segítés és rászorultság olyan új horizontját hozhatják létre, amely a hálózati társadalom sajátosságaihoz igazodik. Ebben a konstellációban a szolidaritás az azonos szenvedési formákat különböző integrációs keretek között megtapasztaló cselekvőket összekötő hálózat potenciális jellemzője, amely időben és kiterjedésében egyaránt rugalmasan szerveződik. Ilyen értelemben a - különböző szintű és integrációs logikájú hálózatok terében betöltött pozíciótól független - szenvedéstapasztalatok hálózatokon átívelő metaintegrációs potenciált rejtenek magukban: képesek arra, hogy különböző integrációs szinteken és logikák szerint szerveződő hálózatok között létesítsenek - alapértelmezésben valószínútlen - kötéseket. A késő modernitás e hálózati szolidaritása - a

12 Ez ugyanakkor nem jelenti azt, hogy ne lennének a szenvedés határállapotainak vagy a kvázi-terápiás hálózatokhoz való hozzáférésnek strukturális összefüggései. Ahogy azt a mentális zavarok szociológiája (Rogers-Pilgrim 2014) vagy a segítő kapcsolatokra vonatkozó elemzések (Dorerian-Fararo 1998; Kovách 2017) részletesen kimutatják, a gazdasági, kulturális, települési, nemi, etnikai vagy éppen életkori különbségek sokasága detektálható ezek vonatkozásában. Minthogy ezen összefüggések annyira nem erősek, hogy koherens tapasztalati terek által szervezett társadalmi nagycsoportokat hozzanak létre, a szenvedés határállapotai átnyúlnak határaikon.

13 Ez praktikusan azt jelenti, hogy ha valamely határállapot irányába mutató torzulást (pl. hangulatzavarok esetében: az instrumentális cselekvés társadalmi korlátozása a sikertelenség társadalmi okainak elleplezésével párosulva) preintencionális szinten (pl. a hatékonyságot elutasító életvilág) tapasztal meg egy cselekvő, egyaránt kapcsolódási pontot talál az intencionális (pl. esszencializáló illúzió) vagy posztintencionális (pl. előítéletes reflexív intézmény) szinten átélt hasonló szerkezetű szenvedéstapasztalatokhoz (Sik 2016b). 
„mechanikushoz” és az „organikushoz” hasonlóan - tehát nem csupán sajátos morális azonosulási lehetőséget biztosít, hanem emellett a késő modern társadalmak sajátos integrációs szükségletének kielégítéséhez is eszközt kínál.

A hálózati szolidaritás természetesen a fenti elemzések alapján leginkább egy lehetőségnek tekinthető. Ha úgy tetszik, arra vonatkozó hipotézis, hogy miként képzelhető el szolidaritás a késő modernitásban. Azt a kérdést, hogy emellett vagy ehelyett milyen - regresszív vagy éppen dezintegrációs - szolidaritási stratégiák jelennek meg, illetve hogy pontosan milyen - hiányzó, diszfunkcionális és adekvát - elemekből áll össze a szolidaritás, empirikus vizsgálatok hivatottak felderíteni.

\begin{abstract}
The article aims to reinterpret the notion of solidarity in the late modernity as a key to integration and moral phenomenology. Firstly, the emergence and the weakening of the paradigm based on social security is analysed from a social historical point of view. Secondly, an attempt is made to outline the possibilities of solidarity in late modernity. Based on the integration model of Bourdieu, Habermas, Giddens and Lash, the adequate (suffering is treated by supporting networks), inadequate (supporting networks are not connected to suffering) and lacking (suffering is not treated) solidarity is mapped. Thirdly, with the help of such typology, the premodern, classical and late modern paradigm of solidarity is elaborated.
\end{abstract}

Keywords: solidarity, late modernity, critical theory

\title{
Irodalom
}

Bauman, Z. (2000): Liquid modernity. Oxford: Blackwell.

Boltanski, L. - Chiapello, È . (1999): Le nouvel esprit du capitalisme. Paris: Gallimard.

Bourdieu, P. (2002): A gyakorlati észjárás: a társadalmi cselekvés elméletéről. Budapest: Napvilág.

Darvas Á. - Szikra D. (2017): Családi ellátások és szolgáltatások. In Ferge Zs. (szerk.): Magyar társadalom- és szociálpolitika (1990-2015). Budapest: Osiris Kiadó, 215254.

Doreian, P. - Fararo, Th. (szerk.): The problem of Solidarity. Theories and Models. Pennsilvania: University of Pittsburgh. Gordon and Breach Publishers.

Durkheim, É. (2000): Az öngyilkosság. Szociológiai tanulmány. Budapest: Osiris.

Durkheim, É. (2001): A társadalmi munkamegosztásról. Budapest: Osiris.

Castel, R. (1998): A szociális kérdés alakváltozásai - a bérmunka krónikája. Max Weber Alapítvány - Wesley Zsuzsanna Alapítvány - Kávé Kiadó.

Castel, R. (2009): La montée des incertitudes : Travail, protections, statut de l'individu. Paris: Ed. du Seuil.

Castel, R. (2016): The rise of uncertainties. Critical Horizons, 17(2): 160-167. DOI: 10.1080/14409917.2016.1153886.

Castells, M. (2010a): The Information Age: Economy, Society, and Culture. Volume I, The Rise of the Network Society. Oxford: Blackwell Publishers. 
Castells, M. (2010a): The Information Age: Economy, Society, and Culture. Volume II, The Power of Identity. Oxford: Blackwell Publishers.

Castells, M. (2010a): The Information Age: Economy, Society, and Culture. Volume III, End of Millennium. Oxford: Blackwell Publishers.

Didry, C. (2001): Symposium sur. Les métamorphoses de la question sociale. Une chronique du salariat. Sociologie du Travail, 43: 235-263.

van Dijk, J. A. G. M. (1999): The one-dimensional network society of Manuel Castells. New Media and Society, 1(1): 127-138.

Duprez, D. (1996): Castel Robert. Les métamorphoses de la question sociale. Une chronique du salariat. Revue française de sociologie, 37-4: 639-642.

FergeZs. (2000): Elszabaduló egyenlőtlenségek. Budapest: Hilscher RezsőSzociálpoltikai Egyesület és az ELTE Szociológiai Intézet Szociálpolitikai Tanszéke.

Ferge Zs. (2012): A gyermekes családok helyzetének változása a válság utáni években. Esély, 6.

Foucault, M. (2004): A bolondság története. Budapest: Atlantisz.

Friot, B. (2001): Symposium sur. Les métamorphoses de la question sociale. Une chronique du salariat. Sociologie du Travail, 43: 235-263.

Giddens, A. (1991): Modernity and Self-Identity. Self and Society in the Late Modern Age. Cambridge: Polity.

Giddens, A. (1996): Out of Place: Anthony Giddens reviews Manuel Castells'. The Rise of the Network Society. Times Higher Education Supplement (December 13).

Garnham, N. (2000): “Information Society” as Theory or Ideology: A Critical Perspective in Technology, Education and Employment in the Information Age. Information, Communication \& Society, 3(2): 139-152. DOI: 10.1080/13691180050123677.

Habermas, J. (2005): Megismerés és érdek. Pécs: Jelenkor.

Habermas, J. (2011): A kommunikatív cselekvés elmélete. Budapest: Gondolat.

Horkheimer, M. (1976): Hagyományos és kritikai elmélet. In Papp Zs. (szerk.): Tény, érték, ideológia. A pozitivizmusvita a nyugatnémet szociológiában. Budapest: Gondolat, 43-116.

Janky B. (2011): Solidarity and Preferences on Welfare Institutions. In Ellison, M. (ed.): Reinventing Social Solidarity Across Europe. Bristol: Policy Press.

Kovách I. (szerk.) (2017): Társadalmi integráció. Az egyenlőtlenségek, az együttmüködés, az újraelosztás és a hatalom szerkezete a magyar társadalomban. Szeged: Belvedere.

Lash, S. (1999): Another Modernity, a Different Rationality. Oxford: Blackwell.

Latour, B. (2005): Reassembling the Social: An Introduction to Actor-network-theory. Oxford: Oxford University Press.

Lévinas, E. (1988): Useless suffering. In Bernasconi, R. - Wood, D. (eds.): The Provocation of Levinas: Rethinking the Other. London: Routledge.

Jollivet, M. (1994): Robert Castel. Les métamorphoses de la question sociale. Une chronique du salariat. Études rurales, 135-136: 185-187.

Marx, K. (1977): Gazdasági-filozófiai kéziratok 1844-ból. Budapest: Kossuth Könyvkiadó. 
Rácz A. (2012): Gyermekszerepben tartott felnőttek. In uő. (szerk.): Gyermekvédelemben nevelkedettek társadalmi integrációs esélyei. Letöltés: http://rubeus.hu/wpcontent/uploads/2013/09/24428_gyermek_es_ifjusagvedelmi_tanulmanyok_ elso_kotet.pdf (utolsó letöltés: 2017. 05. 12.).

Rogers, A. - Pilgrim, D. (2014): A Sociology of Mental Health and Illness. Maidenhead: McGraw-Hill. Open University Press.

Rosa, H. (2010): Social Acceleration: A New Theory of Modernity. Columbia University Press. Sik D. (2012): A modernizáció ingája - Egy genetikus kritikai elmélet vázlata. Budapest: ELTE - Eötvös Kiadó.

Sik D. (2015a): A modernitás rétegei. Budapest: ELTE - Eötvös Kiadó.

Sik D. (2015b): Társadalmi patológia és pszichopatológia A pszichológiai diagnózisok és terápiák haszna a kritikai elmélet számára. socio.hu, 3: 197-222.

Sik D. (2016a): Szerfüggőség kritikai hálózatelméleti perspektívából. Esély, 4: 83-119.

Sik D. (2016b): A depresszió kialakulását valószínűsítő hálózatok. socio.hu, 4: 1-25.

Sik D. (2017): A kritikai elméletek hálózati modellje. Jel-kép, 1.

Sik D. (2018): A szenvedés határállapotai. ELTE - Eötvös Kiadó (megjelenés alatt).

Stern, M. J. (2000): Back to the future? Manuel Castells'. The information age and the prospects for social welfare. Cultural Studies, 14(1): 99-116. DOI: 10.1080/095023800335002.

Stevenson, N. (1998): Contraflows in critical theory. New Political Economy, 3(3): 468473. DOI: 10.1080/13563469808406378.

Takács E. (2009): Közös kaland? A szociológia és a történelem(tudomány) viszonya a XX. századi Franciaországban: A durkheimi paradigma problematikája. Budapest: Equinter Kiadó.

Takács E. (2016): A szolidaritás és a társadalmi együttmúködés az individualizálódott társadalmakban és Magyarországon In Antal A. - Földes Gy. (szerk.): Holtpont: Társadalomkritikai tanulmányok Magyarország elmúlt 25 évérôl. Budapest: Napvilág Kiadó, 219-246.

Tönnies, F. (2004): Közösség és társadalom. Budapest: Gondolat.

Utasi Á. (2002): A bizalom hálója. Mikrotársadalmi kapcsolatok és szolidaritás. Budapest: Új Mandátum.

Utasi Á. (2013): Kötelékben. Szolidaritás-hálók és közélet. Szeged: MTA - Belvedere Meridionale.

Waterman, P. (1999): The brave new world of Manuel Castells: What on earth (or in the ether) is going on? Development and Change, 30(2): 357-380.

Webster, F. (1997): Is this the information age? City, 2(8): 71-88.

Webster, F. (2006): Theories of the Information Society. London: Routledge.

White, H. C. (2008): Identity and Control: How Social Formations Emerge. Princeton, N. J.: Princeton University Press.

Zakariás I. (2016): Szolidaritás és hatalom a kisebbségi magyarokra irányuló jótékonyságban. PhD-értekezés. BCE Szociológiai Doktori Iskola. http://phd.lib.unicorvinus.hu/917/1/Zakarias_Ildiko.pdf (utolsó letöltés: 2017. 05. 12.). 